\title{
ER Stress-Sensor Proteins and ER-Mitochondrial Crosstalk-Signaling Beyond (ER) Stress Response
}

\author{
Vaishali Kumar ${ }^{+}(\mathbb{1})$ and Shuvadeep Maity ${ }^{*}++\mathbb{C}$ \\ Department of Biological Sciences, Birla Institute of Technology and Science (BITS)-Pilani (Hyderabad Campus), \\ Shameerpet-Mandal, Hyderabad, Telangana 500078, India; p20200006@hyderabad.bits-pilani.ac.in \\ * Correspondence: shuvadeep@hyderabad.bits-pilani.ac.in \\ + Equal contribution.
}

check for updates

Citation: Kumar, V.; Maity, S. ER Stress-Sensor Proteins and ER-Mitochondrial

Crosstalk-Signaling Beyond (ER)

Stress Response. Biomolecules 2021, 11, 173. https://doi.org/10.3390/ biom 11020173

Academic Editor: Marco Corazzari Received: 30 November 2020

Accepted: 19 January 2021

Published: 28 January 202

Publisher's Note: MDPI stays neutral with regard to jurisdictional claims in published maps and institutional affiliations.

Copyright: (C) 2021 by the authors Licensee MDPI, Basel, Switzerland. This article is an open access article distributed under the terms and conditions of the Creative Commons Attribution (CC BY) license (https:// creativecommons.org/licenses/by/ $4.0 /)$.

\begin{abstract}
Recent studies undoubtedly show the importance of inter organellar connections to maintain cellular homeostasis. In normal physiological conditions or in the presence of cellular and environmental stress, each organelle responds alone or in coordination to maintain cellular function. The Endoplasmic reticulum (ER) and mitochondria are two important organelles with very specialized structural and functional properties. These two organelles are physically connected through very specialized proteins in the region called the mitochondria-associated ER membrane (MAM) The molecular foundation of this relationship is complex and involves not only ion homeostasis through the shuttling of calcium but also many structural and apoptotic proteins. IRE1alpha and PERK are known for their canonical function as an ER stress sensor controlling unfolded protein response during ER stress. The presence of these transmembrane proteins at the MAM indicates its potential involvement in other biological functions beyond ER stress signaling. Many recent studies have now focused on the non-canonical function of these sensors. In this review, we will focus on ER mitochondrial interdependence with special emphasis on the non-canonical role of ER stress sensors beyond ER stress.
\end{abstract}

Keywords: ER stress; endoplasmic reticulum; mitochondria associated membrane (MAM)

\section{Introduction}

Eukaryotic cells have different membrane-bound compartments or organelle with specific biochemical and biological functions. Initially, to understand cellular homeostasis, understanding a particular organelle and their function was the main focus. In recent days, the crosstalk between different organelles is studied to elucidate their impact on various human diseases [1-3]. Inter-organellar connections are achieved by direct physical contact of the membranes or via membrane bound proteins. These connections are highly regulated and are dynamic in nature [4]. Among different organelles, one of the most studied interactions is between mitochondria and the endoplasmic reticulum (ER). The first evidence of this particular interaction was discovered in rat liver cells in 1952 [5] and $1956[6,7]$ through electron microscopy. Later an elaborate and apparently unique specialization of the endoplasmic reticulum and a precise orientation with respect to the mitochondria has been described for the specific cell of the pseudo-branch gland in teleost $[2,8]$. The isolation of ER-mitochondria contacts was performed $\sim 45$ years ago by density gradient differential centrifugation from rat liver $[9,10]$. Vance subsequently coined the term mitochondria associated ER membranes [MAM] [11]. These functional sites are involved in lipid metabolism, calcium signaling, mitochondrial fission and fusion, ER stress, apoptosis and autophagy [3]. The distance between ER and mitochondria were estimated to be around $100 \mathrm{~nm}$ but later digital imaging microscopy and electron tomography studies proved that, they were at a distance of 10 to $25 \mathrm{~nm}$ during resting conditions, hence, they are referred to as 'tethering of organelles' [12,13]. However, during environmental stress, the contact sites become tighter $(\sim 10 \mathrm{~nm})$ [12]. The molecular foundation of this 
relationship is complex and involves not only ion homeostasis through the shuttling of calcium but also many structural and apoptotic proteins. The important proteins that are involved in the tethering are mitofusin (MFN), inositol triphosphate receptor $\left(\mathrm{IP}_{3} \mathrm{R}\right)$, voltage-dependent anion channel (VDAC), glucose-regulated protein 75 (Grp75), mitochondrial fission 1 protein (Fis1), B-cell receptor-associated protein 31 (BAP31), protein tyrosine phosphatase interacting protein 51 (PTPIP51) and vesicle-associated membrane protein-associated protein B (VAPB) [14]. Studies showed different mitochondrial proteins can regulate the ER stress and Unfolded Protein Response (UPR) pathways. The outer mitochondrial membrane GTPase mitofusin 2 (Mfn2) is known to regulate the shape of endoplasmic reticulum (ER) controlling ER-mitochondrial contacts. Interestingly deletion of Mfn2 causes activation of ER stress [15]. Recently a unique regulation of the ER stress through a 54-amino acid microprotein, PIGB opposite strand 1 (PIGBOS), has been demonstrated. This microprotein localizes to the mitochondrial outer membrane where it interacts with the ER protein CLCC1 at ER-mitochondria contact sites. Loss of PIGBIOS led to activation of UPR [16]. Alternately, a large-scale high throughput study on human cervical cancer cells showed that ER stress can regulate the translations of mitochondrial genes, specifically those involved in mitochondrial localized translation [17].

This review will primarily focus on the ER stress sensors and its relation to ERmitochondrial communication, MAM proteins and its involvement in various cellular functions. A special effort has been taken to discuss recent insights/developments about the non-canonical role of ER stress sensors in different physiological processes beyond its canonical ER stress signaling.

\section{ER Stress and ER Stress Sensors}

Endoplasmic reticulum is an organelle that spans a large area in the cytoplasm in the shape of elongated tubules and flat discs. The presence of ribosomes on the ER makes it Rough ER (RER), while the absence makes it a smooth ER (SER). With the presence of ribosomes, one of the major functions of ER is synthesis, folding, maturation and degradation of secretory and transmembrane proteins. ER plays a crucial role in maintaining the cellular protein homeostasis or proteostasis. Before the export of proteins from ER to Golgi apparatus, the proteins undergo post-translational modifications and folding with the help of chaperons and folding enzymes/foldases such as Protein Disulphide Isomerases (PDI) present in the ER. Proteins such as calnexin and calreticulin act as a quality control for the proteins to ensure if they are properly folded [18].

Many exogenous and endogenous factors such as UV radiation, reactive oxygen species, hypoxia, protein mutations, lipid homeostasis, deletion of genes and nutrient starvation can cause accumulation of misfolded proteins resulting in ER stress. Also, the membrane phospholipid synthesis is important in maintaining the function of the organelles, hence impairment of phospholipid biosynthesis can upregulate the protein quality control pathway such as the UPR of ER or ER-associated protein degradation (ERAD) [19]. For instance, Inositol Requiring Enzyme 1 (IRE1) is activated in the absence of inositol in yeast, as it is essential in the phospholipid metabolism and is required by INO1 gene which encodes inositol-3-phosphate, an enzyme of the phosphatidylinositol synthesis. When UPR occurs, the genes related to lipid biosynthesis are upregulated. In mammals, the spliced X-box binding protein 1 (xbp1) acts as a transcription factor and it subsequently activates the lipid synthesis genes. Direct evidence that lipids may activate the UPR independently was first provided by Promlek et al. (2011) in budding yeast [20]. Similarly, Volmer et al. showed membrane lipid saturation can activate UPR without the accumulation of misfolded proteins in mammalian cells $[20,21]$. The ER stress activation through gene mutation involved in lipid biosynthesis without the presence of any misfolded stress has been observed in C elegans also [22]. Surprisingly, it was noted by Shyu et al. 2019 that stress caused in the lipid bilayer (especially phosphatidylcholine and phosphatidylethanolamine) can induce ER stress in budding yeast and the reduction of UPR to restore the lipid homeostasis is seen in various human diseases, such as non-alcoholic fatty liver, diabetes, cardiac and 
muscle dystrophies. Major perturbations to PC or PE can prematurely degrade certain transmembrane proteins such as sarco/endoplasmic reticulum Calcium-ATPase (SERCA) ion pump, which leads to disturbance in the calcium homeostasis ultimately resulting in ER stress. Also, the Sec61 translocon on the ER gets degraded by Doa10 complex which does not allow the misfolded proteins to exit ER [19]. Eukaryotic organisms switch on the UPR of ER that initiates a cascade of cellular signaling to restore homeostasis and regular ER function [23].

UPR of ER was first studied on yeast, where it is solely regulated by IRE1, while in mammals there are three major proteins involved in controlling ER stress response: IRE1, protein kinase RNA-like endoplasmic reticulum kinase (PERK), activating transcription factor 6 (ATF6) [23] (Figure 1, bottom). These ER stress sensors get activated upon the presence of misfolded proteins and their activation mechanism is still unclear [22,23]. If UPR fails to rescue the cellular protein homeostasis, the cells undergo apoptosis.

These sensors have an ER luminal domain, ER transmembrane domain and a cytosolic domain to pass on signals to other machinery involved in protein functions. Each of these sensors act independently to attenuate translation (in case of PERK) and induce expression of UPR target genes (IRE1, ATF6) [24]. When there are no stress conditions prevailing, these proteins remain bound to a heat shock protein 70 chaperon (Hsp70) called BiP. When misfolded proteins are detected, these sensors are released from BiP. This is followed by oligomerization of PERK and IRE1. Trans-auto-phosphorylate at their cytosolic domains activate their downstream signaling pathway. ATF6 is transported to the Golgi for its further actions [25].

IRE1(also known as ERN1, for ER to nucleus transducer 1) is a highly conserved UPR sensor protein with kinase and RNase activity [26] (Table 1). IRE1 and its downstream transcription factor HAC1/IRE2 (the yeast ortholog of the metazoan XBP1) were first identified as a factor required for growth in the medium deprived of inositol [26,27]. Inositol is an essential building block of yeast phospholipids. IRE1, a type 1 transmembrane protein, has both serine/threonine (S/T) kinase domain and an RNAse domain. In the search for the mammalian counterpart two groups independently identified two homologs of IRE1, named IRE1 alpha and IRE1 beta [28-30]. IRE1 $\alpha$ is found ubiquitously while IRE1 $\beta$ is restricted to the intestinal epithelium. During ER stress the IRE1 is activated through direct or indirect activation by the misfolded proteins [31,32]. A subsequent oligomerization of the cytoplasmic domain of IRE1 leads to the activation of the RNase domain which splices introns from mRNA encoding the XBP1 [33]. The transcriptionally active XBP1 induces expression on genes such as Glucose regulated protein (GRP78), Protein disulphide isomerase (PDI) and other translocation proteins to regulate the protein folding during ER stress [34]. Also, it activates the expression of heat shock protein $40 \mathrm{kDa}$ (DnaJ), p58, ERresident molecule (ERdj4), ER degradation-enhancing $\alpha$-mannosidase-like protein (EDEM) involved in ERAD and ER-to-Golgi transport components [25,35-38]. However, in the case of prolonged or unresolved ER stress, IRE1 $\alpha$ cleaves various mRNAs localized in the ER through a process called Regulated IRE1 $\alpha$ dependent decay (RIDD) [39,40].

ATF-6 is a leucine zipper protein, which is encoded by ATF6A for ATF6 alpha and ATF6B for ATF6 beta (Table 1). It is activated in the ER by misfolded proteins and exported to the Golgi where it gets cleaved by a protease; membrane-bound transcription factor peptidase, site1 (S1P). Approximately 400 amino acids from its N-terminal region are cleaved off and now it activates different UPR gene expression in the nucleus. Combining IRE1 and PERK activity, ATF6 also activates XBP1 and CHOP to enhance the UPR signaling pathway $[25,41,42]$. 


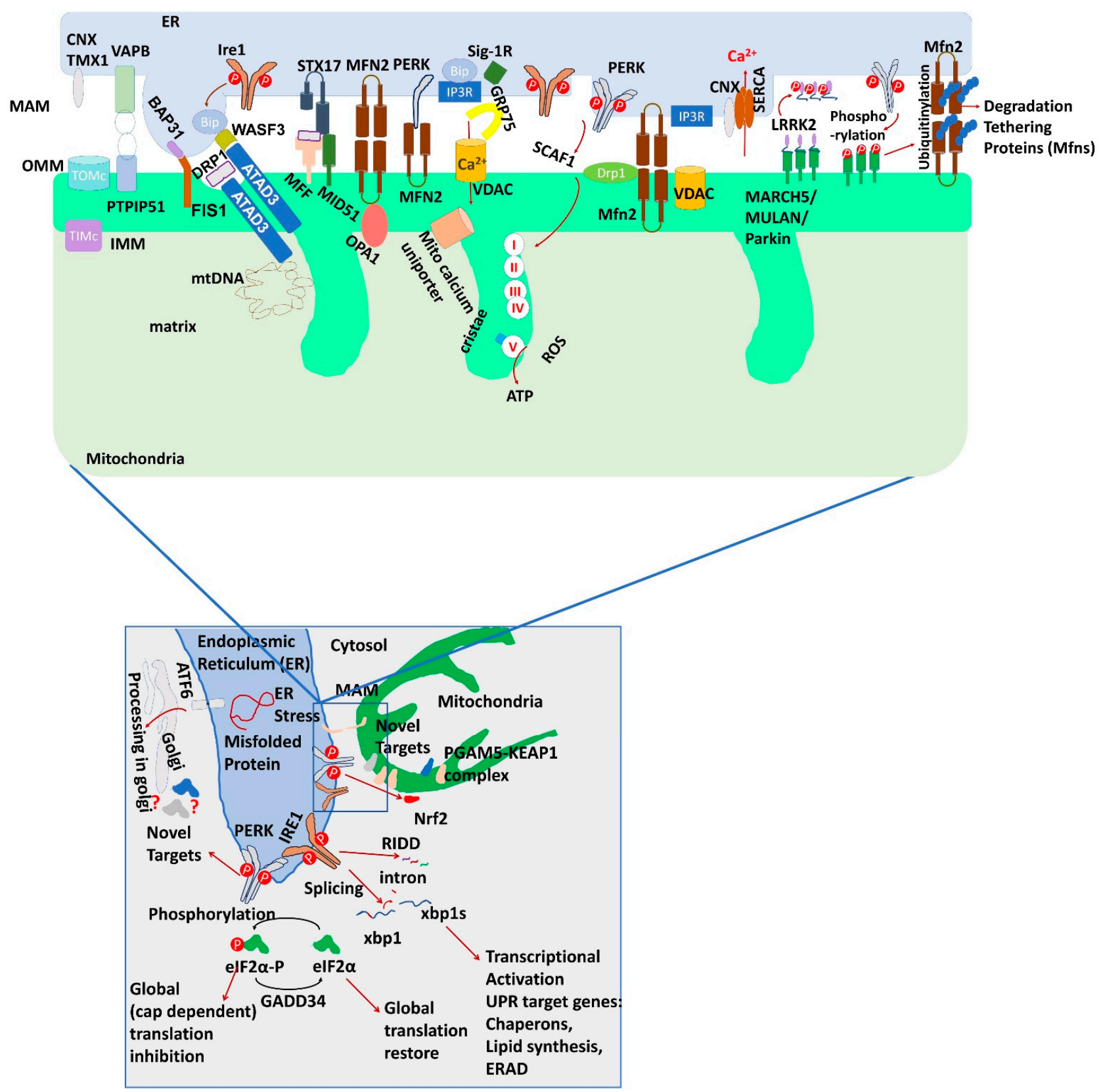

Figure 1. Endoplasmic reticulum (ER) mitochondrial contact: membrane dynamics, signaling and involvement of ER stress sensors. (Top), the schematic representation of ER-mitochondrial contact with key molecular contributors and their known functional interactions are summarized. MAM proteins are generally anchored either on the ER or outer mitochondria surface. Some MAM proteins like ATAD3A span from the inner mitochondrial membrane to ER -Mito contact site. Calcium transfer between ER-Mitochondria regulates through different channel proteins distributed throughout the MAM site. IP3R on the ER membrane transfers calcium from ER lumen to the mitochondria which is mediated by GRP75 and is taken up by VDAC at OMM and transferred to IMM via MCU. SERCA formulates the return of calcium to ER. SIGMA 1R protects IP3R from ERAD. TIMC/TOMC, protein translocase complexes of IMM and OMM mediating mitochondrial protein import. TMX-1 at MAM forms a functional complex with Calnexin (CXN) and SERCA to modulate calcium flux. VAPB an ER integral membrane protein and PTPIP51 an OMM protein interact with each other to regulate lipid transfer. MFN2 in ER and mitochondria/ MFN1 in mitochondria are tethering proteins which can also regulate calcium homeostasis. MAM proteins, LRRK and PERK control ubiquitination pathway dependent mitochondrial tethering process. MARCH5/MULAN/PARKIN modulates the structure of MAM through degradation via LRRK mediated MFN2 ubiquitinoylation. Mitochondrial dynamics are maintained by the fission fusion process. Successful mitochondrial fission 
requires coordination of ER resident STX17 with mitochondria bound Mff and MiD51 via DRP1 to initiate mitochondrial fission. Similarly, for fusion processes MFN2 and OPA1 interact with each other. ATAD3A forms a ternary complex involving ATAD3A, WASF3 and MAM associates GRP78 to regulate cell proliferation during metastasis. ATAD3 complex with cytosolic DRP1 controls mtDNA maintenance. PERK/eIF2 $\alpha$ /ATF4 axis transcriptionally controls SC assembly factor 1 (SCAF1) levels to maintain the formation of respiratory supercomplexes. (Bottom), schematic representation of ER stress activation upon accumulation of misfolded proteins. UPR sensors PERK, IRE1 $\alpha$, ATF6, is activated due to the stress. Auto phosphorylated/Activated PERK phosphorylates the eIF2 $\alpha$ that results in attenuation of global protein translation. GADD34 can dephosphorylate eIF2 $\alpha$ making the translation attenuation transient. PERK can activate latent NRF2 in the cytoplasm to enhance the survival of cells. Phosphorylated cytosolic domain of IRE1 $\alpha$ cleaves the introns from XBP1 mRNA which then encodes for XBP1s protein. It induces the expression of UPR target genes, chaperons, ERAD. IRE1 degrades a set of mRNAs in the ER termed IRE1-dependent decay of mRNAs (RIDD). Activated ATF6 is transported to the Golgi where it is proteolytically cleaved to an active form. Now it enters the nucleus to induce expression of UPR target genes. MAMs have been shown to be a hot spot for the transfer of stress signals from the ER to mitochondria specially during the loss of ER homeostasis. Details of all the abbreviations are at the end.

Table 1. Unfolded Protein Response (UPR) sensors from yeast to mammals.

\begin{tabular}{|c|c|c|c|}
\hline & & & References \\
\hline \multirow{10}{*}{ UPR proximal sensor } & $\begin{array}{c}\text { Yeast } \\
\text { Saccharomyces cerevisiae }\end{array}$ & IRE1 & {$[26,43]$} \\
\hline & \multirow{3}{*}{$\begin{array}{l}\text { Metazoans } \\
\text { C. elegans }\end{array}$} & IRE1 & \multirow{3}{*}[26,44]{} \\
\hline & & Pek-1 & \\
\hline & & atf6 & \\
\hline & \multirow{3}{*}{$\begin{array}{c}\text { Fly } \\
\text { Drosophila melanogaster }\end{array}$} & IRE1 & \multirow{3}{*}{ [45] } \\
\hline & & PEK1 & \\
\hline & & atf6 & \\
\hline & \multirow{3}{*}{ Mammals } & $\begin{array}{c}\text { IRE1 } \alpha \text { (ubiquitous) } \\
\text { And IRE1ß (only in Gut) }\end{array}$ & {$[30,45,46]$} \\
\hline & & PERK/PEK & {$[46,47]$} \\
\hline & & $\begin{array}{l}\text { ATF6 } \alpha \text { and } \\
\text { ATF6ß }\end{array}$ & {$[48,49]$} \\
\hline \multirow{4}{*}{$\begin{array}{l}\text { Downstream transducers of } \\
\text { Proximal sensor }\end{array}$} & $\begin{array}{c}\text { Yeast } \\
\text { Saccharomyces cerevisiae }\end{array}$ & Hac1 & {$[34,50]$} \\
\hline & $\begin{array}{l}\text { Metazoans } \\
\text { C. elegans }\end{array}$ & XBP1 & {$[51,52]$} \\
\hline & $\begin{array}{c}\text { Fly } \\
\text { Drosophila melanogaster }\end{array}$ & xbp1 & [42] \\
\hline & Mammals & $\begin{array}{l}\text { XBP1 } \\
\text { eIF2 } \alpha\end{array}$ & {$[33,53]$} \\
\hline
\end{tabular}

PERK is a major sensor protein identified from rat pancreatic islets, which identifies the imbalances in the ER during the stress conditions and resolves it by reducing the overall translation. The activation of PERK during ER stress is still unclear but after its activation, it can selectively bind to the misfolded proteins and not the native proteins [23,25] (Table 1). The ubiquitously expressed PERK has luminal and cytosolic serine/threonine domains. The BiP removal from the luminal domain is involved in the oligomerization and transautophosphorylation step which results in the activation of PERK [25]. The activated PERK phosphorylates serine 51 (Ser 51) of the alpha subunit in the eukaryotic translation initiation factor 2 alpha (eIF $2 \alpha$ ). The phosphorylation of eIF $2 \alpha$ results in the inhibition of eIF2B, thus it eventually reduces the initiation of the global translation process and the subsequent protein load in the ER. The phosphorylation also results in translation of mRNAs encoding for several factors such as activating transcription factor 4 (ATF4), BiP, GRP94, XBP1, ATF6. During ER stress, all the above-mentioned proteins are required to improve cellular homeostasis. Some of the PERK associated pathways that are involved in 
ER-Stress induced apoptosis are PERK/eIF2 $\alpha /$ ATF4, PERK/CaN, PERK/eIF2 $\alpha /$ TDAG51, PERK/eIF2 $\alpha /$ IAP2 and PERK/NRF2 [53,54]. One of the main downstream targets of eIF2 $\alpha$ ATF4 is CCAAT/enhancer-binding protein homologous protein (CHOP). The promoter site of CHOP has binding sites for the UPR activators such as ATF4 and ATF6. CHOP induces apoptosis by activating pro-apoptotic factors such as death receptor 5 (DR5), Bim and telomere repeat binding factor 3 (TRB3) and inhibits anti-apoptotic factors such as BCL-2 [55]. The negative feedback loop in the mechanism is played by growth arrest and DNA damage-inducible 34 (GADD34), as it can dephosphorylate eIF2 $\alpha$ and restart the protein synthesis [25].

\section{Proteins at ER and Mitochondria Contact Site and Its Function}

Mitochondria-endoplasmic reticulum (ER) contact sites are maintained by the physical interactions between the outer mitochondrial membrane (OMM) and the ER surface that run in parallel at a constant distance. The juxtaposition between these organelles controls several signaling pathways involving different kinds of proteins including ER stress sensor proteins (Figure 1, top). While MAM research progressed in the mammalian system very rapidly, the one in the yeast was studied less progressively [56]. Later in yeast few novel players have been identified that contributed to ER mitochondrial contact sites [57]. In yeast, MAM is termed as ER-mitochondria encounter structure (ERMES). The complex contains 4 proteins; Mdm10 and Mdm34, these are integral outer mitochondrial membrane (OMM) proteins, Mmm1, an integral ER membrane protein and Mdm12, a cytosolic protein $[2,14,58]$. These are involved in lipid exchange, calcium transfer, protein import, mitochondrial motility and genome maintenance [58]. Studies showed that mutations to this ERMES complex resulted in morphological defects in the mitochondria and altered lipid homeostasis [58].

The overall MAM protein complex in higher organisms is more advanced in their functionality than the ERMES complex and there are no exact homologs for the core proteins that are present in the yeast model. There are many proteins present in the MAM complex that attribute to the stability of the tethering model [2] (Table 2). Advancement of different microscopic techniques enables us to assess ER-mito contacts in a variety of live and fixed samples. In addition, assays based on co-localization markers with confocal or advanced super resolution microscopy provide sufficient resolution to detect the physiologically relevant interfaces between ER and mitochondria [59-61]. For example, structured illumination microscopy (SIM) helped to understand the role of DISC1, a MAM protein, in controlling mitochondrial dynamics and neuronal morphogenesis [62]. Moreover, new insights over VAPB-PTPIP51 interaction and ER-mitochondria associations during amyotrophic lateral sclerosis / frontotemporal degeneration (ALS/FTD) can be possible using these techniques [59]. Several other indirect approaches like fluorescence resonance energy transfer (FRET) based calcium sensors, yeast two hybrid screening, split luciferase assays have been instrumental in understanding the role of ER-mitochondrial dynamics [63-65]. Few new players in the MAM have recently been identified through proximity-based techniques (APEX coupled with mass-spectrometry). These approaches are effective not only to identify new players but also to confirm the existence of known MAM proteins as well [66,67]. Reticulon1A (RTN1A) promotes ER mitochondrial contacts and ribosomebinding protein 1 (RRBP1) as a binding partner for SYNJ2BP modulates ER-mitochondrial tethering have been identified from the two different APEX studies. Among other known MAM, these screen also found significant enrichment of an important MAM component, ATPase family AAA domain-containing protein 3 (ATAD3A) which is involved in several physiological processes including mitochondrial biogenesis, lipid biosynthesis and steroid biosynthesis, mtDNA maintenance, mitochondrial connectivity and mitophagy [68].Very recently, Kwak et al. (2020) introduced a split-pair system of BioID, CONTACT-ID, for identification of the MAM proteome in live cells $[68,69]$. This approach successfully identified 115 MAM-specific proteins. In addition, it also revealed membrane topologies of 85 integral membrane proteins. This study established FKBP8 (also known as FKBP38) as a 
new MAM protein. Previously this protein was known for its involvement in apoptosis under the stress conditions [70], Sonic hedgehog signaling [71] and mitophagy [72]. FKBP8 is an essential player in MAM formation and its expression level controls calcium Ion transport from ER to the Mitochondria. The various functions of different MAM proteins are being discussed further.

\subsection{Lipid Homeostasis}

The MAM is the main site for non-vesicular phospholipid and cholesterol transport and also the synthesis of certain intermediates during lipid synthesis. ER serves as the major site for membrane lipid synthesis while the mitochondrial membrane has high levels of phospholipids and low levels of sterols and sphingolipids. Mitochondria receives phosphatidylserine (PS) synthesized by the ER which is then converted to phosphatidylethanolamine (PE) by mitochondrial PS decarboxylase enzyme. This PE is transported back to ER for its conversion to phosphatidylcholine (PC), which is finally given to mitochondria for its membrane synthesis $[73,74]$. Proteins such as oxysterol-binding protein (OSBP)- related protein 5 and 8 (ORP5/8) is involved in the transport of phospholipid between two organelles. The exact mechanism of transport of PS to mitochondria from ER is not studied well but members of the oxysterol-binding protein (OSBP) family are involved. Along with this, cholesterol is being transferred from ER to mitochondria with the help of STARD1 protein [75]. This STARD1 protein binds to the OMM and transfers the cholesterol to the IMM where it is processed by CYP11A1 [76-78]. Abatement of function to any of these proteins will affect the interaction between mitochondria and ER and also the function of other proteins involved in tethering [2,3]. Lipid homeostasis has also been controlled by another MAM protein, ATAD3. It is a nuclear-encoded ATPases family protein specific to multicellular eukaryotes. The protein associated with diverse cellular activities and essential for normal mitochondrial-ER interactions. RNAi mediated suppression of ATAD3 homologue (ATAD-3) in C. elegans leads to reduction of intestinal fat content along with low mitochondrial activity [79]. Similarly, studies on human subjects also found deletion of ATAD3 clusters has adverse effects related to cerebellar dysfunction. At molecular level, ATAD3 deficiency led to aberrant mtDNA organization and is associated with elevated free cholesterol and increased expression of genes involved in cholesterol metabolism [80].

\subsection{Calcium Transport}

Calcium is an important intracellular messenger involved in various signaling mechanisms. ER and mitochondria are the hubs for calcium transfer and storage. Transfer of calcium between these two organelles are important for a cell's life and death cycle and mitochondrial division [81]. The concentration of calcium ions is approximately $1 \mathrm{mM}$ inside the ER while it is near 100nM in the cytosolic region [82].

On the ER and OMM, $\mathrm{IP}_{3} \mathrm{R}$ and VDAC channels are present in close proximity and are regulated by the chaperon GRP75. From the ER calcium is released through IP3R and is transferred to the OMM via VDAC. Calcium eventually travels into the IMM through mitochondrial calcium uniporter (MCU). The site of calcium transfer is also regulated by the mitofusin in the mammalian cell. MFN 2 on the ER surface interacts with MFN 1 and MFN 2 on the mitochondrial membrane. When the calcium release from the ER is reduced, Sig-1R on the membrane of ER is released from BIP/GRP78 to stabilize IP3R and promote prolonged ER calcium release. Overexpression of any of these molecules leads to the excess calcium storage in mitochondria which can trigger apoptosis or can ignite the ER stress response mediated apoptosis [64,65].

Besides the above-mentioned MAM proteins, the functional characterization of an ER protein, PDZD8, has established its role in ER mitochondrial tethering. This protein is conserved in mammals and metazoans. In neurons, PDZD8 regulates the cytoplasmic $\mathrm{Ca}^{2+}$ dynamics through the balance between mitochondrial calcium uptake after synaptically induced $\mathrm{Ca}^{2+}$-release from ER [83]. Interestingly, a recent study found post- 
translational modifications by fatty acid can also play a crucial role in maintenance of calcium homeostasis via MAM proteins. Harada et al. 2020 demonstrated palmitoylated cytoskeleton-associated protein 4 (CKAP4) regulates mitochondrial functions through an interaction with VDAC2 at ER-mitochondria contact sites. Knockout of CKAP4 in various in vitro cell models and mice models showed morphological changes of mitochondrial and ER. In addition, palmitoylation of CKAP4 is essential in the formation of ER-mitochondria contact sites, $\mathrm{Ca}^{2+}$ influx into mitochondria, mitochondrial respiration and cancer cell proliferation. Hence, presence of MAM proteins is essential not only to maintain calcium homeostasis between ER and mitochondria but also regulate mitochondrial respiration and survival of cells.

\subsection{Apoptosis}

As a defense mechanism, when a cell is damaged by disease or during a stress response it undergoes apoptosis, while the exact signals triggering apoptosis in MAM is still unknown. The proteins at MAM directly or indirectly play a critical role in apoptosis. The excess release of calcium from the ER into the ER-Mitochondria interface can stimulate apoptosis. The calcium flux opens the mitochondrial permeability transition pore (MPTP with the help of cyclophilin D (CYPD), thus propagating Cytochrome C release, caspase cascade and, ultimately, apoptosis. The caspase targets BAP31 at the ER membrane and allows it to bind to FIS1 at the outer mitochondrial membrane (OMM), activating pro-caspase $8[3,81,82,84]$. PACS-2 an ER sorting protein is bound to Bid, a BH3-only protein family is important in ER-mitochondria coupling. During apoptosis by sustained ER stress PACS-2 releases Bid to mitochondria where it is cleaved by caspases to form activated truncated $\mathrm{Bid}(\mathrm{tBid})$, which promotes cytochrome $\mathrm{C}$ release and death. $\mathrm{tBid}$ can facilitate the accumulation of Bax/Bak in the OMM which are proapoptotic. The entire apoptotic signaling can be controlled by the presence of $\mathrm{Bcl}-2$ family proteins in the ER as they bind to inositol-1,4,5-triphosphate (InsP3) receptors $\left(\mathrm{IP}_{3} \mathrm{R}\right)$ and inhibit calcium release. Several studies have shown that association with Bcl-2 family proteins, including BIM, helps stabilization of IRE1 $\alpha$ oligomers to work against apoptosis during calcium overload [85-87]. In contrast, IRE1 $\alpha$ as a member of MAM controls cell survival by splicing the Xbp1 mRNA [88-90]. In a neuronal cell line (SH-SY5Y), IRE1 $\alpha$ knockdown causes cell death, through accelerated $\mathrm{Ca}^{2+}$ release from the ER. Induction of InsP3R increases ER $\mathrm{Ca}^{2+}$ release resulting in cell death due to prolonged mitochondrial $\mathrm{Ca}^{2+}$ accumulation and alterations in morphology (swelling and fragmentation) and function [91]. Anti-apoptotic miRNA is degraded by IRE1 $\alpha$. It results in increased mRNA and protein expression of TXNIP and caspase-2 [92,93]. ER stress sensor PERK has initially been identified as a crucial member at the MAM and transmits apoptotic signals from the ER to mitochondria [69]. The downstream target of PERK is CHOP, a proapoptotic gene that suppresses transcription of BCL-2 genes and stimulates the expression of Bax and Bim. CHOP can also increase Ero1 $\alpha$ expression that favors calcium release from IP3R stimulating apoptosis [94].

\subsection{Autophgy}

In all eukaryotes, autophagy is a conserved process to maintain cellular homeostasis by auto digesting the unwanted or damaged parts of a cell. The molecular basis of the mechanism is well studied in yeast and around 30 autophagy-related genes (Atg) have been identified, out of which 18 are essential for autophagosome emergence. These Atg proteins are conserved from yeast to humans and they have similar functions [95].

Autophagosome is a structure that encompasses a damaged part of a cell and then fuse with the lysosome, this can originate from the ER-mitochondria contact sites called the isolation membrane. Autophagy is initiated by isolation membranes, which then fuses with the lysosomes to degrade the cellular components. But the origin of this isolation membrane was in debate, as they thought it can arise from either ER, mitochondria or plasma membrane [96,97]. Hamasaki et al., have performed imaging studies to show that autophagosomes form at the ER-mitochondria contact sites. The data revealed that the 
autophagosome marker ATG14, part of the PI3K complex that is essential for autophagosome formation, was found to be localized at the MAM during the starved condition of the cell $[98,99]$ and is placed on the ER under normal conditions but during starvation, it diffuses through the ER membrane [100,101]. Electron tomographic studies showed that in presence of sufficient amino acid there was no localization of ATG14 on MAM but during starvation, accumulation of ATG14 was markedly observed at the MAM along with double FYVE domain-containing protein (DFCP1), a protein that can act as a platform for autophagosome formation [102]. Localization towards ER and mitochondria were seen throughout the process but the association with ER was stable while that with mitochondria was found only during amino acid starvation. ATG14 complex, as well as DFCP1, re-localizes to the MAM fractions during starvation. By these results, Axe et al. (2008) proved that ER gave the stage for autophagosome formation, while mitochondria have a role in providing components required for the same [102]. Live-cell imaging also showed that eventually when the expression of mitochondrial protein VDAC1 was increasing, the expression of ATG14 slowly decreased showing the end of autophagy. This again proves that the process of autophagy occurs at the MAM site [103]. Another ER protein known as STX17, it is known to be a Qa-SNARE protein, also localized at MAM during starvation but its exact function is not known yet [104]. It was also proved that STX17 was upstream of ATG14 and is responsible for the recruitment of ATG14 to MAM during any stressful conditions.

To elucidate the relationship between ER stress, autophagy and apoptosis, Ji et al., performed a few experiments on osteosarcoma cell lines. Osteosarcoma is a tumor of the bone where the proliferating spindle cells produce immature bone [105]. The study established the role of ER stress sensor PERK in autophagy. Ekaterina BobrovnikovaMarjon et al. found that PERK protein was readily detectable in all 7 carcinoma cell lines compared to non-transformed breast epithelial cell line. PERK promotes tumor growth and proliferation by limiting progression of cell cycle through oxidative DNA damage checkpoints [106]. It also helps the cells to adjust during hypoxic stress by altering angiogenesis [106,107]. This study, for the first time, showed PERK is highly expressed in osteosarcoma cells and it is involved in a protective mechanism such as autophagy. During ER stress the PERK activation is more and PERK- mediated autophagy is a protective function against apoptosis of the osteosarcoma cells. This is protective as the activated PERK may inhibit mTORC1 pathway and inhibit apoptosis by enhancing autophagy under stress conditions. But knockdown of PERK may enhance the ER stress in osteosarcoma cells and also switch on the mTORC1 pathway which will inhibit autophagy and increase cellular apoptosis. Loss of PERK function may inhibit autophagy and makes the cell sensitive to stress-causing apoptosis [108].

Mitophagy is a selective form of autophagy in which mitochondria are specifically degraded [109]. The PINK1/PARKIN pathway is the most well studied pathway of mitophagy. It has been found that PINK1 and BECN1 re-localize at mitochondria-associated membranes during mitophagy and promote the ER mitochondria tethering $[109,110]$. It is not surprising that later it was found few MAM proteins are actively involved in the mitophagy process. For example, FUNDC1 is a novel MAM protein required for hypoxiainduced mitophagy [111]. Numerous studies have convincingly demonstrated the crucial role of macro-autophagy and mitophagy in the commitment and differentiation of stem cells. MAM protein, Atad3a is involved in the maintenance of human progenitor cells via the PINK/PARKIN arm of mitophagy [111-113]. Deletion of Pink1 in Atad3a-deficient mice rescued mitophagy related defects which in turn resulted in the restoration of the progenitor and hematopoietic stem cell pools [111,112].

Evidence shows that ER stress plays a major role in neurodegenerative diseases, like Parkinson's disease (PD). It is characterized by the accumulation of mutant alpha-synuclein protein at the ER and an overload of this causes ER stress which activates the IRE1, PERK or ATF6 pathway. The study by Yan et al. 2019 showed that the accumulation of toxic proteins triggers the IRE1 and brings autophagy-dependent neuron death in Drosophila model [114]. 
This marks the onset and progression of neurodegeneration in PD. This autophagy was mediated by the JNK pathway independent of XBP1 protein. While the presence of XBP1 offered neuroprotective effects upon dopaminergic neurons in PD [114,115].

\subsection{Maintenance of Mitochondrial Dynamics and ER-Mitochondrial Physical Contact}

Mitochondria are highly dynamic organelle and undergo constant structural reorganization for the maintenance of mitochondrial and cellular function by contributing to the proper distribution of mitochondria in response to the metabolic needs of the cell for ATP [116-118]). As de novo synthesis of mitochondria is not possible, thus mitochondria undergo fusion/fission events to enable proper distribution of mitochondria inside cells $[119,120]$. Mitochondrial outer membrane mediates mitochondrial fission by recruiting the master fission mediator Dynamin-related protein (DRP1, the yeast ortholog of it is DNM1L) from the cytosol to mitochondria [121-123]. DRP1 circumscribes the OMM as a helical oligomer and hydrolyses the GTP causing a conformational change in the oligomer that cleaves the membrane and triggers fission. Other proteins involved in this process are the mitochondrial fission factor (Mff) [124-126] and the mitochondrial dynamics proteins MiD49 and MiD51 (also known as MIEF2 and MIEF1, respectively) which are responsible for the recruitment of DRP1 to the OMM. Optic atrophy 1(OPA1), an inner mitochondrial protein regulates mitochondria morphology and energetics of mitochondria through mitochondrial fusion. It participates in the fusion process by maintaining the cristae structure [127-130]. Interestingly, along with the mentioned protein physical contact with ER plays a significant role. Voeltz research group identified a three-dimensional structure of ER-mitochondria in yeast using electron microscopy which revealed ER tubules were associated with mitochondria which formed the constriction sites. Due to these constriction sites, the diameter of the mitochondria reduced to $140 \mathrm{~nm}$ from $210 \mathrm{~nm}$ approximately enabling the fission process [131]. In both yeast and mammalian cells, the accumulation of these proteins is found in the site where ER tubules circumference the mitochondria. Thus, the juxtaposition between the endoplasmic reticulum (ER) and mitochondria is a common structural feature that facilitates the mitochondrial fission/fusion process.

\subsection{Metabolism}

Apart from protein synthesis and degradation, a variety of metabolic pathways, such as gluconeogenesis, glycogen synthesis and breakdown, membrane lipid synthesis and recycling, fat storage and hormone and drug metabolism are also controlled by ER. MAM proteins are also involved in regulation of the metabolic pathways. For example, the VDAC at the outer mitochondrial membrane interacts with IP3R through the molecular chaperone glucose-regulated protein 75, allowing $\mathrm{Ca}^{2+}$ transfer from the ER to mitochondria [103]. Recent studies demonstrated that MAM proteins play a significant role in the insulin signaling pathway. IP3R gets phosphorylated by Akt localized in MAM [132,133] and thus reducing $\mathrm{Ca}^{2+}$ release and preventing apoptosis $[132,134]$. mTORC2 can also be found in the MAM interface and its presence increases in response to growth factors stimulation [133]. Finally, tumor suppressor phosphatase and tensin homolog is also localized in MAM and sensitizes cells to apoptosis by countering Akt-mediated phosphorylation of IP3R [135].

It was further demonstrated that MAM integrity is required for insulin signaling in the liver [136]; UPR sensors like IRE1 and PERK are involved in AKT signaling events controlling mitochondrial structure and glucose metabolism. In glioma cells, PERK silencing inhibits growth during low glucose stress through partially blocking AKT activation and subsequent inhibition of Hexokinase II (HK2)'s mitochondria translocation [137]. Interestingly, (PKB/AKT-mTOR) signaling controls the dynamics of IRE1 deactivation by regulating ER-mitochondria physical contacts as well as the autophosphorylation state of IRE1 [138]. Metabolic regulation through different MAM proteins including IRE1 and PERK definitely demonstrated a complex regulation through organellar communication. Similarly, an interesting metabolic regulation has been observed in neuronal cells. Neuronal functions and maintenance are highly dependent on glucose metabolism. Specific glucose transporters 
circulate glucose across the blood-brain barrier to the neurons, where it is converted to pyruvate via glycolysis [139]. This pyruvate is further metabolized to acetyl-CoA via mitochondrial respiration. A minor part of glucose metabolism in neurons occurs via hexosamine biosynthesis pathway (HBP) where the proteins are added with $\mathrm{N}$-acetylglucosamine, which can be sensitive to mild fluctuations of glucose metabolism $[139,140]$. Harg et al. demonstrated that activation of UPR has a considerable effect on glucose metabolism in human neuro-blastoma [141]. When there is increased UPR there is a reduction in the O-GlcNAc modified proteins, not due to the reduced amount of glucose in the cells but it is due to the direct effect of UPR on HBP along with a decrease in mitochondrial respiration. This reduction in mitochondrial respiration or ATP production is not due to a decrease in mitochondrial number or changes in its morphology, rather due to UPR activation. Through a systematic screening of UPR specific inhibitors Harg et al. for the first time, revealed the involvement of IRE1 in determining the overall metabolic state of the cell [141].

\section{7. mtDNA Maintenance}

Although mitochondria and the ER have an intimate functional relationship, there has been no evidence that they are inherited in a coordinated manner during mitosis until Liza Pon group for the first time demonstrated the mitochondrial inheritance in yeast through ER-mitochondria tethering. Swayne et al. showed a role for cortical Endoplasmic Reticulum (cER) in anchorage of mitochondria in the bud tip. Mmr1p which has a homology with tethering complex proteins can associate with mitochondria and ER and localizes to opposing surfaces of mitochondria and cER enabling the inheritance of the organelle in daughter cells [142]. Further, it has also found that the distribution of mitochondria and mitochondrial DNA in yeast are linked to ER associated mitochondrial division sites [143]. Later ER-mitochondria contacts also found to be involved in mtDNA synthesis with mitochondrial division in human cells [144]. Importantly, mtDNA integrity is also crucial in the context of neurodegeneration. ATAD3A, a MAM protein, interacts with Drp1 in striatal neurons derived from Huntington's disease (HD) patient-iPSC cells. ATAD3A forms oligomers which bridge Drp1-mediated mitochondrial fragmentation and mtDNA instability, leading to impaired mitochondrial biogenesis and neurodegeneration [145].

\section{Role of ER Stress Sensor Proteins in ER-Mitochondrial Communication and Beyond}

\subsection{IRE1}

The role of IRE1 is extremely diverse due to its broad-spectrum role in various cellular processes; however, it has been majorly implicated in ER stress. Few recent studies have identified its new role specifically in the context of ER-mitochondrial communication. It has been found that the AKT-mTOR signaling axis modulates the dynamics of IRE1 RNAse activity by regulating ER-mitochondria contact. The study demonstrated a two-step mechanism of IRE1 attenuation. The auto-phosphorylation first initiates the termination of IRE1 RNAse activity but the complete cessation of RNAse activity only occurs if ERmitochondria contacts are reformed after their initial uncoupling by ER stress [138]. IRE1 controls expression of GRP78 upon ER stress. During ER stress GRP78 plays a significant role in the stabilization of WASF3 on mitochondrial membranes. Interestingly another MAM protein ATAD3 forms a ternary complex involving ATAD3A, WASF3 and MAM associates GRP78. ATAD3A, acts as a crucial mediator to promote cell invasion in breast and colon cancer via regulating GPR78-mediated stabilization of WASF3 [146].

Besides its canonical role in ER stress several new reports establish involvement of IRE1 in different physiological processes. Interestingly a recent study on yeast identified iRE1/hac1 splicing pathway is essential for cellular adaptation upon diauxic shift via mitochondrial enlargement. They demonstrated IRE1 dependent increase of mitochondrial gene expression upon diauxic shift [147]. Similarly, in higher organisms, the non-canonical function of IRE1 $\alpha$ also determines the mitochondrial calcium uptake. IRE1 $\alpha$ deficiency alters mitochondrial metabolism in vivo. Through mutagenesis analysis, Carreras-Sureda et al. successfully dissected out the housekeeping gene property of IRE1 $\alpha$ and uncovered 
a contribution of IRE1 $\alpha$ to the maintenance of MAM composition and function even in the absence of ER stress. IRE1 $\alpha$, itself, determines the distribution of inositol-1,4,5trisphosphate receptors at MAMs. This study proposed a new model that establishes the fact that IRE1 $\alpha$ operates as a scaffold that stabilizes InsP3Rs at MAMs [148]. Not only controlling ER-mitochondrial dynamics and mitochondrial calcium uptake IRE1 $\alpha$ plays a very crucial role in terms of cell survivability. Mitochondrial ubiquitin ligase (MITOL/MARCH5) inhibits ER stress-induced apoptosis through ubiquitylation of IRE1 $\alpha$ at the mitochondria-associated ER membrane (MAM). This is the first study that shows the regulation of IRE $1 \alpha$ activity by ubiquitylation through a mitochondrial protein. MITOL promotes K63-linked chain ubiquitination of IRE1 $\alpha$ and subsequently prevents hyperoligomerization of IRE1alpha and regulates IRE1 $\alpha$-dependent decay (RIDD) $[138,149]$. Additionally, MITOL also ubiquitylates another MAM protein mitofusin 2 (Mfn2) [150]. It enhances the GTPase activity of Mfn2, resulting in the tethering between the ER and mitochondria rather than mitochondrial fusion (Sugiura et al., 2013). Interestingly, it is already known that Mfn2 can also modulate the UPR and mitochondrial function via repression of PERK, another ER stress sensor and a member of MAM [151]. All these indicate a complex interrelation of ER stress sensors in controlling ER mitochondrial communication beyond its canonical role.

\subsection{PERK}

Accumulation of misfolded proteins inside ER activates PERK through its dimerization and auto-phosphorylation. The serine/threonine (S/T) kinase PERK relieves folding pressure through eIF $2 \alpha$ phosphorylation mediated translation shutdown and increases ER proteostasis mainly through the transcriptional activation of ATF4 [152]. Beyond this canonical role, PERK is also involved in various UPR-independent signaling functions. Cullinan et al. 2003 identified PERK mediated activation of nuclear factor-erythroid-2related factor 2 (NRF2) transcription factor for cell survival [153]. Later Agostinis group demonstrated that PERK is absolutely essential in ER mitochondrial sites to convey apoptosis during ROS induced ER stress [87]. Later several other studies also establish that PERK facilitates the propagation of different signaling routes from the ER to juxtaposed mitochondria by tethering these organelles. Munoz et al. found repression of PERK can control mitochondrial function. Mfn2 is a novel PERK modulator and its deficiency causes mitochondrial dysfunction through sustained activation of PERK [151]. It was also observed that PERK-regulated translational attenuation reduces mitochondrial protein import through the degradation of the TIM23 subunit TIM17A [154]. The Mfn2 -PERK signaling might also be linked through microRNA mediated signaling. During ER stress, miR-106b-25 cluster is repressed by the Perk-dependent transcription factors Atf 4 and Nrf2 [155]. Conversely, another independent study demonstrated that Mir106b mediated Mfn2 suppression is absolutely required for mitochondrial fusion via PKM2 [156]. Taken together it can be concluded that during ER stress while PERK leads to Mir106b repression it may subsequently modulate mitochondrial fission. A very recent study has shown that during ER stress there is a dynamic remodeling of mitochondrial morphology by promoting protective stress-induced mitochondrial hyper fusion (SIMH) through PERK by depleting Yme11 [157]. A recent study identified a direct link between the PERK mediated ubiquitination pathway and another MAM component, Leucine-rich repeat kinase 2 (LRRK2). It was found that LRRK2 regulates endoplasmic reticulum-mitochondrial tethering and mitochondrial bioenergetics. LRRK2 regulates the activities of E3 ubiquitin ligases MARCH5, MULAN and Parkin via kinase-dependent protein-protein interactions. When the Kinase-active LRRK2(G2019S) becomes dissociated from these ligases, it leads to their PERK-mediated phosphorylation and activation. PERK mediated phosphorylation of those ligases, in turn, induces ubiquitin-mediated degradation of ER-mitochondrial tethering proteins [158].

Not only PERK mediated ER mitochondrial connection but also PERK dependent ER plasma membrane connection is crucial in maintaining cellular homeostasis during ER 
stress. Using proximity-dependent biotin identification (BioID), Vliet et al. identified the actin-binding protein Filamin A (FLNA) as a key PERK interactor. Loss of PERK results in disturbed actin cytoskeleton and increased cortical F-actin [159].

Starvation or nutrient deprivation has a significant impact on mitochondrial morphology and enhances mitochondrial hyper fusion to balance mitochondrial bioenergetic efficiency [160]. Nutrient stress due to glucose starvation demands a cellular energetic shift from cytosolic glycolysis to mitochondrial oxidative phosphorylation (OXPHOS) system in order to maintain cellular growth and survival [161]. Moreover, nutrient starvation can also enable ER stress by disrupting protein folding and glycosylation in the ER. In a recent study, Balsa et al. demonstrated how ER communicates with OXOPHOS system to increase ATP production and promote proteostasis in the cell through a previously unknown mechanism controlled by PERK. The study found that PERK activation during ER stress and glucose deprivation stimulates mitochondrial bioenergetics through the formation of respiratory supercomplexes (SCs). PERK activation mediated increase in SCs elevates mitochondrial respiration in cells expressing PERK but not in PERK depleted cells. Additionally, PERK activation also resulted in changes in cristae formation and the formation of cristae is absolutely required in SC formation during nutrient and ER stress. PERK/eIF2 $\alpha /$ ATF4 axis transcriptionally controls SC assembly factor 1 (SCAF1) levels to maintain the formation of respiratory supercomplexes. Interestingly, the PERK dependent mechanism can restore the defects in patients with complex I mutations, thus proving PERK activation can be future targets for mitochondrial diseases [162].

A direct link between PERK mediated control on insulin resistance has recently been demonstrated by Biddinger group [163]. This study again is an example of novel regulation in metabolic control through PERK. The authors found that trimethylamine $\mathrm{N}$-oxide (TMAO) binds to PERK at physiologically relevant concentrations and selectively activates the PERK mediated induction of the transcription factor FoxO1, a key driver of metabolic disease. TMAO which is derived from gut microbiota is increased by insulin resistance and associated with several metabolic syndromes in humans. At pathologically relevant concentrations, TMAO binds and activates PERK and subsequently promotes hyperglycemia. Inhibition of TMAO synthesizing enzyme, flavin-containing monooxygenase 3 (FMO3), with 3,30 -diindolylmethane reduces PERK Activation and Insulin resistance in vivo suggesting a potential route of the therapeutic intervention for metabolic syndrome.

Brown adipose tissue (BAT) is one of the major tissues involved in thermogenesis and plays an important role in metabolic function that contributes to energy consumption (Cannon \& Nedergaard, 2004). During brown adipose tissue differentiation, phosphorylation of PERK happens without any ER stress. This PERK phosphorylation induces transcriptional activation by GA-binding protein transcription factor $\alpha$ subunit $(\mathrm{GABP} \alpha)$, which is required for mitochondrial inner membrane protein biogenesis. This study also demonstrated that $\mathrm{p}$-PERK controls mitochondrial and thermogenic gene expression via transcriptional activation by GABP $\alpha$ and UCP1-mediated thermogenesis in vitro and in vivo [164].

\subsection{ATF6}

ATF6 is the third sensor that plays a significant role in activation of ER stress pathways. Unlike IRE1 and PERK, Atf6 is unique for its specialized activation process. Upon ER stress, the ATF6 traffics from the ER to the Golgi apparatus followed by a sequential cleavage. The cleaved active form acts as a transcription factor of various genes to restore ER homeostasis. Though it is not a MAM component, it is also involved in different non canonical processes controlling organelle homeostasis beyond ER stress. The protective role of Atf6 beyond the canonical role during ER stress has already been observed while overexpression of only ATF6 arm led to activation of protective remodeling of ER proteostasis pathways $[165,166]$. Stress independent activation of ATF6 transcription factor in various in vitro cellular models selectively reduces secretion and extracellular aggregation of destabilized amyloid disease-associated proteins. No significant changes have been observed after selective overexpression of ATF6 on the secretion of endogenous proteome $[167,168]$. 
Recently Burkewitz et al. 2020 demonstrated the loss of atf6 promotes longevity in C elegans. Interestingly, the life span extension is not through canonical proteostasis pathways but through the modulation of ER-mitochondrial calcium homeostasis. Atf- 6 regulates the ER function and lifespan through its proximal mediator, calreticulin/crt-1. As a downstream effect, the ER calcium release further leads to changes in mitochondrial dynamics and bioenergetics [169]. Not only in C elegans, another study conducted by Wang et al. 2018 with human mesenchymal stem cells (hMSCs) also showed that ATF6 can control the aging through maintaining organelle homeostasis. Inactivation of ATF6 led to organelles' dysfunction and accelerated cellular senescence, a process in which FOS functioned as one of the mediators [170]. Not only stem cells, Druelle et al. (2018) found significant changes in ER morphology during cellular senescence in normal human dermal fibroblasts (NHDFs). Senescent NHDFs also exhibited activation of UPR along with ER expansion. Knockdown of Atf6 $\alpha$ inhibited ER expansion, the modification of senescence-associated cell shape and decreased senescence-associated $\beta$-galactosidase activity [171]. Besides this non canonical regulation, maintenance of mitochondrial biogenesis and function are also controlled during ER stress via Atf6 and PGC1 $\alpha$. In hepatoma cell line, expression of estrogen-related receptor gamma (ERR $\gamma)$, a regulator of mitochondrial function, has been enhanced by ATF6 $\alpha$ and PGC1 $\alpha$ [172].

Earlier ATF6 got its attention when it was found to be extremely important for adaptive response during Ischemia/Reperfusion (I/R). The canonical ATF6-dependent ER stress response genes conferred protection from $I / R$ damage in ex vivo isolated perfused heart preparations and maintained contractile function [173]. Further studies on transgenic mice with ATF6 fused to the mutant mouse estrogen receptor (MER) gradually established the idea that the function of ATF6 was much broader than the canonical ER stress response [174]. Another subsequent study using the same mouse model determined ATF6 specific regulation of particular microRNA that can control the activity of ER luminal calcium-binding protein, calreticulin (Belmont et al., 2012). Overexpression of the active ATF6 transcription factor in the heart also has been shown to improve cardiac performance in mouse models of ischemic heart disease, through a mechanism involving ATF6-dependent regulation of the antioxidant gene, catalase [175]. Very recently using conditionally deleted cardiac myocyte specific ATF6 knockout mouse (ATF6 cKO) showed exacerbated myocardial damage in comparison to wild type (Blackwood et al., 2019b). The study also found ATF6 was required to induce the expression of a small GTP-binding protein, Rheb, and, thus, control the mTORC1-dependent growth in pathological hypertrophy. Similarly, another tissue specific role of ATF6 has been observed in the liver. Insulin sensitivity has been improved significantly after overexpression of the active ATF $6 \alpha$ transcription factor in the liver of obese mice [176]. Gain- and loss-of-function studies in mouse livers and in hepatocytes also identify ATF $6 \alpha$ mediated increase of hepatic fatty acid oxidation through coactivation of PPAR $\alpha$ to attenuate hepatic steatosis [177]. In the mouse studies ATF6 denotes the Atf6 $\alpha$ which is expressed in all cell types.

The control of ER function and mitochondrial function have historically been studied as separate entities. But recent studies accumulated enough evidence of overlapping metabolic and signaling pathways for coordinated action of ER and mitochondria. Although UPR and its sensors (IRE1, PERK and ATF6) have classically been linked to ER stress, increasing evidence suggests that the sensors have various non-canonical functions in various cellular processes beyond secretory pathway surveillance during ER stress. Specifically, IRE1 and PERK as a member of MAM are directly involved in various signaling events that establish coordinated function with mitochondria and other cellular organelle.

\section{MAM Proteins (IRE1 and PERK) in Neuronal Disease}

Neurodegenerative diseases are characterized by the depletion of neuronal cells and damage to the axons, dendrites and synaptic buttons that ultimately lead to neuronal death. Parkinson's disease (PD), Alzheimer's disease (AD), Hereditary spastic paraplegias (HSP), Frontotemporal dementia (FTD), Amyotrophic lateral sclerosis (ALS) and Charcot 
marie tooth (CMT) are some of the major NDD [178]. Association between mitochondriaassociated ER-membrane (MAM) and neurodegenerative disorders (NDD) are an important area of research. Deregulation in certain proteins present at the MAM can alter the function of neurons, its response to stress stimuli or influence the neuroinflammatory response of NDD [179]. Some of the major roles of MAM are associated with calcium homeostasis, mitochondrial dynamics and autophagy. In NDD all the above-mentioned functions are impaired as many proteins involved in NDD reside in MAM [99]. The proteins involved in $\mathrm{AD}$, dementia, motor neuron disease, neuropathy, schizophrenia and chorea are abundantly present in MAM and deregulation in any of the proteins affect the cross-talk between ER and mitochondria [180].

$\mathrm{AD}$ is most commonly seen in elderly people and is associated with the formation of intracellular tangles of hyperphosphorylated tau and formation of plaques by beta-amyloid peptides, due to the cleavage of amyloid precursor proteins by beta and gamma-secretase which has a core dimer of Presenilin 1 and 2 (PS1, PS2) [181]. It is found that PS1 and PS2 are enriched at MAM and affect the communication between ER and mitochondria. When the Ps 1 or 2 are knocked out, the calcium transfer between ER and mitochondria and phospholipid synthesis is increased. This phospholipid increase can act as an important marker for finding AD [182,183]. Also, dysregulation of phosphofurin-acidic cluster sorting protein and sigma1R in MAM is a hallmark for AD, as sigma $1 \mathrm{R}$ is the master regulator for Tau phosphorylation. When the lipid bilayer of MAM has disrupted it results in the abnormal production of beta-amyloid peptides leading to AD [74].

One of the hypotheses on AD pathology so far is dependent on the abnormal structure of mitochondria and impaired function of MAM. But apart from proteins present at the MAM, AD brain also shows an increase in chronic UPR activation by increasing the levels of Grp78, phosphorylated PERK (pPERK), phosphorylated IRE1 $\alpha$, phosphorylated eIF2 $\alpha$ $(\mathrm{p}$-eIF2 $\alpha$ ) and ATF4 [184,185]. There are multiple studies that establish the intricate link between IRE1 $\alpha$ and its role in AD [186]. In AD patients, accumulation of IRE1 is seen in the hippocampus region resulting in granulovacuolar degeneration in neurons [185]. The phosphorylated IRE1 activates XBP1 splicing which is found to be higher in the cortical areas of patients with AD and not in age matched normal subjects [187]. Also, the $116 \mathrm{C} / \mathrm{G}$ polymorphism of XBP1 is a major risk factor for AD [188]. The overexpression of this downregulated ryanodine receptor 3 expression results in calcium dyshomeostasis in the cytosol leading to beta-amyloid toxicity [189]. Hence, targeting IRE1 can result in reduced amyloid deposits, improved cognitive and synaptic function and attenuated astrogliosis [190]. In the case of PERK, activation of ATF4 increases the pro-apoptotic cascades leading to apoptotic cell death in AD [191]. UPR activation also results in the accumulation of granulo-vacuolar degenerating bodies (GVDs), an autophagic vacuole produced by the smooth ER which encapsulates ubiquitinated protein for autophagic destruction [192,193]. The tau protein is localized along with GVDs and enhances the ER stress and intensifies the PERK's immunoreactivity [194]. Studies on tau and its action on PERK are not well studied but PERK's action over tau has been studied by several groups. pPERK activates GSK3 beta (implicated in tauopathy), which in turn activates the caspases leading to cleavage in tau. This caspase cleaved tau accumulates in the brain and is an indicator for pre-tangle pathology in AD $[188,189,195,196]$. Recently, direct PERK activation has been explored for neuroprotection by compound CCT020312 in models of tauopathies [197].

PD is characterized by loss of dopaminergic neurons in the substantia nigra pars compacta and the presence of Lewy bodies, cytosolic inclusions largely composed of alphasynuclein. This alpha-synuclein is found in the MAM and its mutant variety affects the morphology of MAM and its calcium transfer between the organelles [198]. PTEN-induced kinase 1 encoded by the gene PINK1 is located at the mitochondrial outer membrane acting as a quality control protein and allows the binding of parkin protein to the dysfunctional mitochondria and causes autophagy of the same [199]. If the gene is silenced in the case 
of PD it reduces the contact between ER and mitochondria and deducts its biological functions [199-201].

During PD in dopaminergic neurons, there is also an increase in the levels of pPERK and p-eIF2 $\alpha$ [202]. The major protein of PD, synuclein has no effect on UPR and is only associated with MAM and its dysfunction, hence UPR is a therapeutic target in this case [23,203]. A recent study on Drosophila exposed to heat-induced ER stress showed that PERK mediated attenuation of protein synthesis resulted in neuronal survival during heat stress. When the PERK-eIF2 $\alpha$ pathway was impaired, there was dopaminergic neuron loss and decreased locomotor activity [203].

ER stress is an important contributor to the pathological implication in PD and accumulation of IRE1 is a major cause of this [204]. Ablation of XBP1 can be neuroprotective to dopaminergic neurons, this can be achieved by increasing the expression of UPR chaperons such as calreticulin and disulphide isomerase ERp72 in substantia nigra pars compacta $[115,204]$. A study on Drosophila elucidated that a mild ER stress-activated IRE1 pathway and not the CHOP regulated apoptosis in PD condition. While if we knock down the expression of XBP1 during PD, the CHOP pathway may get activated and result in neurodegeneration [205]. Targeting this pathway can promote dopaminergic neurons and neural stem cell survival and improves the symptoms of PD [205,206]. Recently a study using the Drosophila model showed that XBP1 independent overexpression of IRE1 resulted in autophagy-dependent neuron death via JNK pathway, [115]. The Leucine-rich repeat kinase 2 (LRRK2) gene is one of the most important genes in familial Parkinson's disease (PD). Toyofuku et al. (2020) identified the role of LRRK2 in the ER-mitochondrial tethering, which is essential for mitochondrial bioenergetics. LRRK2 regulates endoplasmic reticulum-mitochondrial tethering through the PERK-mediated ubiquitination pathway [158].

Diseases affecting the peripheral nervous system by affecting the motor neurons are also linked to dysfunction in MAM. It includes Hereditary spastic paraplegias (HSP), a term used to describe a group of inherited NDD characterized by progressive weakness and spasticity [207]. HSP is majorly caused by an alteration in the SPAST gene encoding spastin, which is a microtubule-serving ATPase that has a role in axonal transportation and cytoskeleton organization. Along with spastin atlastin-1 and receptor expression enhancing protein 1 (REEP-1) it coordinates the connection between ER and microtubules [208]. When SPAST gene gets deleted, it causes a malfunction in the ER structure and function, resulting in defective MAM [64]. CMT is very complex and causes defects to the peripheral nervous system. Mfn2 was the first protein found in the MAM region and it is found to be mutated in the case of CMT type 2a. The mutations in Mfn2 are scattered in its $\mathrm{C}$ and $\mathrm{N}$ terminal both of which are extended into the cytosol, hence it causes defects in the tethering process of ER and mitochondria [209].

ALS is a late-onset fatal NDD, occurring sporadically and causes loss of motor neurons and muscle weakness [210]. The genes associated with ALS are antioxidant protein superoxide dismutase1(SOD1), TAR-DNA binding protein 43 (TDP-43), vesicle-associated membrane protein-associated protein B (VAPB) and valosin containing protein [211]. VABP is a resident at MAM and regulates the normal functioning of the same. When VAPD and TDP- 43 are mutated the MAM is dysregulated by altered calcium homeostasis and impaired mitochondrial axonal transport. Sigma receptor 1 is located at MAM and is highly mutated during ALS and affects the lipid metabolism [212]. In the case of ALS, mutant forms of TDP-43 and SOD1 are upregulated during PERK activation resulting in the formation of stress granules [23]. They are aggregates of mRNAs, ribosomal subunits and other proteins formed due to the attenuation of translation by prolonged phosphorylation of eIF2 alpha $[213,214]$. ER-mitochondria interactions are perturbed by TDP-43, a protein pathologically linked to amyotrophic lateral sclerosis and fronto-temporal dementia. The perturbation is associated with disruption to the VAPB-PTPIP51 interaction and cellular $\mathrm{Ca}^{2+}$ homeostasis [215]. PERK regulates the development of ALS via several routes, for example, by affecting SOD1. SOD1 is an enzyme with three different isoforms. 
Cytosolic and mitochondrial intermembrane space-localized isoforms bind to copper or zinc ions and perform dismutation of free superoxide radicals. The SOD1 mutant form interacts with Bip and increases ER stress and mitochondrial oxidative phosphorylation. It also activates PERK and its downstream pathway. Higher expressions of p-eIF2 $\alpha$ and ATF4 were observed in transgenic ALS (SOD1 ${ }^{\mathrm{G} 93 \mathrm{~A}}$ ) mouse spinal cords [216]. Several other studies also indicated the potential link between mutant and familial forms of ALS [217,218]. Though the actual cause of ALS (90\% sporadic ALS) is elusive but only with respect to PERK the regulation is found to be at different levels. For example, haploinsufficiency of PERK significantly accelerates disease onset and shortens the survival of G85R mutant SOD1 transgenic mice which is phenotypically a model of familial ALS $[219,220]$. Moreover, PERK mediated induction of expression of two other chaperones, BIP and PDI, has been observed in SOD1 mutant lines. In addition, studies on ALS patients and mouse models demonstrated the PERK interaction of with Sigma1R, another MAM protein that is associated with ALS/FTD [221], suggesting the involvement of MAM remodeling in the development of ALS.

Huntington's disease (HD) is caused due to the expansion in CAG repeat in the exon 1 of the huntingtin gene, which translates into a polyglutamine (polyQ) tract in the huntingtin (Htt) protein [222]. The expansion (above 35 glutamine residues) of the polyQ repeats causes mutant $\mathrm{Htt}(\mathrm{mHtt})$ to aggregate in HD tissues [223]. It damages the striatum and cerebral cortex but the exact pathway or mechanism is still unclear [224]. There are various types of Huntington's disease-like syndromes (HDL) such as HDL- 2, 3 and 4 each showing different repeat expansion in different sets of chromosomes [225]. A mutant form of Huntingtin protein induces ER stress and levels of p-eIF2 $\alpha$ are high in mutant Huntingtin [226]. Overexpression of mutant Huntington increases the PERK pathway and also increases the levels of Grp78 but if we target and reduce the phosphorylation at eIF2 $\alpha$, the toxicity caused by PERK can be reversed [226,227]. In the case of HD, the presence of p-IRE1 has been detected in striatal tissues of HD patients and it stimulates the aggregation of Huntingtin protein along with TRAF 2 (TNF- receptor-associated factor 2) which in turn induces neuronal cell death. Few mouse model studies showed the presence of XBP1 in the striatum of HD patients while it was absent in the cerebellum and cortex of the same subjects [228-230]. Evidence shows that ablation of XBP1 can reduce the accumulation of mutant proteins by increasing the expression of FoxO1 dependent autophagy pathway and enhancing motor neuron performance and neuronal survival (Wei et al. 2016). Another recent study also confirms that the sensitivity of the striatal neurons towards pathogenic HD is through the PERK-eIF2 $\alpha$ pathway [231]. This study also demonstrated that the PERK pathway is strongly downregulated in striatal neurons compared to other cell types and brain regions in WT mice. In HD condition it has been upregulated. In the follow-up study, the Lederkremer group very recently showed PERK activator MK-28 can successfully reduce toxicity and extend survival in Huntington's disease models [232].

Mutant ATAD3A contributes to neurodegenerative diseases affecting both peripheral and central nervous systems [233]. In conditions such as HD, ATAD3A exhibits a gain of function through oligomerization which causes mitochondrial fragmentation and impaired mitochondrial biogenesis leading to neurodegeneration. In HD cells, ATAD3A interacts with DRP1 (mitochondrial fission GTPase) and induces mitochondrial fragmentation. By blocking this interaction, mitochondrial fragmentation and mtDNA damage can be suppressed which ultimately reduces HD pathology [145].

Progressive supranuclear palsy (PSP) is an NDD with several phenotypes and also a type of tauopathy formed due to the accumulation of defective tau proteins with four MT-binding repeats in regions such as basal ganglia, diencephalon, brainstem and cerebellum [234]. Activation of PERK is seen in PSP human tissues and pPERK increases the level of tau proteins [235]. Eukaryotic translation initiation factor 2 alpha kinase 3 (EIF2AK3) encodes PERK. A GWAS study by Schellenberg and colleagues identified EIF2AK3 as a risk factor for PSP [236]. Several SNPs were found in coding as well as non-coding regions of EIF2AK3. These various SNPs in the EIF2AK3 genes can acts as a novel therapeutic 
target $[235,236]$. We have summarized a table (Table 2) describing the major MAM proteins categorized according to their functional role [237-255].

Table 2. Major mitochondria-associated ER-membrane (MAM) proteins and its functions.

\begin{tabular}{|c|c|c|c|c|}
\hline S.no & Role & Protein & Function & Reference \\
\hline \multirow{10}{*}{1} & \multirow{10}{*}{$\begin{array}{l}\text { Mitochondrial dynamics } \\
\text { and morphology }\end{array}$} & VAPB & $\begin{array}{l}\text { Regulates ER-Mitochondria interactions and also binds } \\
\text { to PTPIP51 in mitochondria to regulate different } \\
\text { functions at MAM. }\end{array}$ & [59] \\
\hline & & DISC1 & $\begin{array}{l}\text { Regulates mitochondrial dynamics by regulating } \\
\text { calcium transfer. }\end{array}$ & [62] \\
\hline & & CKAP4 & $\begin{array}{l}\text { Regulates mitochondrial respiration, survival and } \\
\text { calcium influx. }\end{array}$ & {$[81,82]$} \\
\hline & & Opa 1 & Tether and fuse the inner membrane of the organelle. & {$[84]$} \\
\hline & & Fis1 & $\begin{array}{l}\text { Binds to Drp1 during fission and also alters the } \\
\text { morphology of mitochondria based on ATP or calcium } \\
\text { availability. }\end{array}$ & {$[84]$} \\
\hline & & PERK & $\begin{array}{l}\text { Essential as ER mitochondrial contact to convey } \\
\text { apoptosis on ROS based ER stress. }\end{array}$ & [87] \\
\hline & & MFN 1 and MFN 2 & Involved in fusion and tethering to other organelles. & [237] \\
\hline & & Drp 1 & Involved in fission. & [238] \\
\hline & & $\begin{array}{l}\text { Mff } \\
\text { and } \\
\text { MIEF } 1 / 2\end{array}$ & $\begin{array}{c}\text { Works together and recruits Drp1 to mitochondria } \\
\text { during the fission process. }\end{array}$ & [238] \\
\hline & & PACS 2 & $\begin{array}{l}\text { Key regulator for the communication between ER and } \\
\text { mitochondria. }\end{array}$ & [239] \\
\hline \multirow{8}{*}{2} & \multirow{8}{*}{ Calcium homeostasis } & PDZ8 & Regulates cytoplasmic calcium dynamics. & [83] \\
\hline & & VDAC1 & $\begin{array}{l}\text { Gatekeeper for the transport of calcium in and out of } \\
\text { the mitochondrial membrane. }\end{array}$ & [241] \\
\hline & & Sig-1R & $\begin{array}{l}\text { Stabilizes IP3R and promotes prolonged ER } \\
\text { calcium release. }\end{array}$ & [241] \\
\hline & & HSPA5 & $\begin{array}{l}\text { Regulator for calcium signaling and cell survival } \\
\text { at MAM. }\end{array}$ & [240] \\
\hline & & PSEN1/2 & Regulate calcium homeostasis at MAM. & [242] \\
\hline & & RyR2 & Calcium-binding proteins located at MAM. & [243] \\
\hline & & IP3R & Mediates release of calcium from ER into the cytosol. & [244] \\
\hline & & ITPR1/3 & $\begin{array}{l}\text { Mediate release of calcium from ER, transport calcium } \\
\text { to mitochondria by interacting with VDAC, calcium } \\
\text { overload at ER lumen can initiate apoptosis via ITPR. }\end{array}$ & [245] \\
\hline \multirow{6}{*}{3} & \multirow{6}{*}{ Lipid homeostasis } & SERCA 1 & $\begin{array}{l}\text { Involved in intracellular mitochondrial trafficking and } \\
\text { phosphatidylglycerol remodelling. }\end{array}$ & [19] \\
\hline & & ATAD3A & Involved in lipid and sterol transport. & {$[68,69]$} \\
\hline & & ACAT & $\begin{array}{c}\text { Helps in the conversion of free cholesterol into } \\
\text { cholesterol esters at MAM. }\end{array}$ & [242] \\
\hline & & STARD1 & $\begin{array}{l}\text { Important for the synthesis of steroids at the } \\
\text { mitochondrial inner membrane interacts with VDAC } \\
\text { and transports cholesterol to mitochondria. }\end{array}$ & [244] \\
\hline & & ERLIN1/2 & $\begin{array}{l}\text { Maintain cholesterol homeostasis by selective binding } \\
\text { and also involved } \\
\text { in ERAD. }\end{array}$ & [246] \\
\hline & & CAV 1 & $\begin{array}{c}\text { Act as lipid raft scaffolds and cholesterol } \\
\text { binding domain. }\end{array}$ & [247] \\
\hline
\end{tabular}


Table 2. Cont.

\begin{tabular}{|c|c|c|c|c|}
\hline S.no & Role & Protein & Function & Reference \\
\hline & & Sig 1- R & $\begin{array}{l}\text { Chaperone involved in lipid synthesis and transport at } \\
\text { MAM. }\end{array}$ & [248] \\
\hline & & PEMT & $\begin{array}{l}\text { Catalyzes the methylation for } \\
\text { phosphatidylethanolamine to phosphatidylcholine. }\end{array}$ & [249] \\
\hline & & ORP5/8 & Controls transport of phospholipid at MAM. & [250] \\
\hline & & ACSL 4 & $\begin{array}{l}\text { Converts long-chain fatty acids into their active form, } \\
\text { involved in intracellular lipid storage and transports } \\
\text { cholesterol from ER to mitochondria. }\end{array}$ & [251] \\
\hline \multirow{10}{*}{4} & \multirow{10}{*}{$\begin{array}{l}\text { Apoptosis, Autophagy } \\
\text { and Mitophagy }\end{array}$} & CHOP & $\begin{array}{l}\text { Induces apoptosis by activating death receptor } 5 \text { (DR5), } \\
\text { BIM and telomere repeat binding factor } 3 \text { (TRB3) and } \\
\text { inhibits anti apoptotic factors such as BCL-2. }\end{array}$ & {$[41]$} \\
\hline & & FKBP8 & $\begin{array}{l}\text { Controls Apoptosis, mitophagy via calcium } \\
\text { level regulation. }\end{array}$ & {$[70]$} \\
\hline & & Cyclophilin D & $\begin{array}{c}\text { Regulates the release of cytochrome } \mathrm{C} \text { and caspases } \\
\text { from mitochondria by opening the mitochondrial } \\
\text { permeability transition pore (MTTP). }\end{array}$ & {$[84]$} \\
\hline & & $\mathrm{BAP}+\mathrm{FIS1}$ & $\begin{array}{l}\text { Interact with each other to activate pro caspase } 8 \text { and } \\
\text { induce apoptosis. }\end{array}$ & [84] \\
\hline & & STX17 & $\begin{array}{l}\text { Involved in mitophagy during hypoxic conditions or } \\
\text { other cellular stress conditions. }\end{array}$ & [104] \\
\hline & & PARK 2 & $\begin{array}{l}\text { It is a pro autophagic protein which induces } \\
\text { ubiquitination and proteasomal degradation at OMM. } \\
\text { It inhibits fusion and induces mitophagy. }\end{array}$ & [110] \\
\hline & & PINK 1 & $\begin{array}{c}\text { Act as a quality control protein to mitochondria, helps } \\
\text { in tethering of MAM and induces mitophagy in } \\
\text { stressful conditions. }\end{array}$ & [110] \\
\hline & & FUNDC 1 & $\begin{array}{l}\text { Involved in mitophagy during hypoxic conditions or } \\
\text { other cellular stress conditions. }\end{array}$ & [111] \\
\hline & & $\mathrm{AKT} / \mathrm{mTOR}$ & $\begin{array}{l}\text { Proteins of this pathway are localized at MAM and at } \\
\text { mild ER stress, they are triggered to induce autophagy } \\
\text { as a protective mechanism. }\end{array}$ & [133] \\
\hline & & ATG 14 & $\begin{array}{l}\text { Regulates the formation of autophagosomes and acts } \\
\text { as an autophagosome marker. }\end{array}$ & [252] \\
\hline \multirow{5}{*}{5} & \multirow{5}{*}{ Metabolism } & PIGBOS & $\begin{array}{l}\text { Interacts with CLCC1 and regulates UPR and } \\
\text { cell survival. }\end{array}$ & [16] \\
\hline & & IRE1 & $\begin{array}{l}\text { IRE1 signaling induces a reduction in glucose } \\
\text { metabolism in neurons. }\end{array}$ & [141] \\
\hline & & PERK & $\begin{array}{l}\text { PERK is required for the hyperglycemia induced } \\
\text { by TMAO }\end{array}$ & [164] \\
\hline & & Akt & $\begin{array}{c}\text { It reduces calcium release by phosphorylating Ip3 and } \\
\text { reduces apoptosis. This phosphorylation is regulated } \\
\text { by the glucose level and it maintains insulin } \\
\text { homeostasis. }\end{array}$ & [254] \\
\hline & & PP2A & $\begin{array}{l}\text { It regulates the structure and function of MAM by the } \\
\text { amount of glucose present. High glucose content } \\
\text { reduces PP2A thus it gets activated and } \\
\text { phosphorylates downstream MAM proteins. }\end{array}$ & [255] \\
\hline 6 & MAM tethers & $\begin{array}{l}\text { Reticulon 1A (RTNIA) } \\
\text { Ribose-binding protein } \\
1 \text { (RRBP1) + Binding } \\
\text { protein of SYNJ2B }\end{array}$ & Increase the extent of MAM contacts. & {$[66,67]$} \\
\hline
\end{tabular}




\title{
6. Conclusions
}

Conclusively, MAM site is a hot spot for the transfer of signals between the ER and mitochondria. Along with other MAM proteins, IRE1 and PERK, two membrane bound ER stress sensors, regulate signaling events not only during stress but also in several other physiological processes. Undoubtedly, new studies have described non-canonical roles of ER stress sensor beyond its stress response signaling. As a MAM component, both can interact with several other mam proteins to convey signaling that controls cell survivals. IRE1 $\alpha$ regulation of RNAs (mRNAs and miRNAs) is an elegant process that manages to handle multiple cellular functions, apart from its decisive role in ER stress. Similarly, PERK has diverse regulation from interaction with ER-mitochondria to ER plasma membrane in controlling cellular bioenergetics to calcium transport maintenance. Though ATF6 is not present at MAM, it has important non-canonical role beyond ER stress. Therefore, a thorough understanding of these protein molecules and their involvement in diverse cellular events are needed to understand the complicated roles of these sensors beyond ER stress. Valid questions include: Apart from misfolded proteins, how cellular homeostasis mechanisms can be coupled with activation/inactivation of IRE1 $\alpha$ and PERK? How different organelle contact influences cellular homeostasis through these ER stress sensors? Does PERK have additional targets beyond eIF2alpha like NRF2 controlling ER mitochondrial communication? An enhanced understanding of these two players can lead to targeted therapeutic interventions as these two molecules are highly involved in the development of different diseases including neurodegenerative disease through different pathways.

Author Contributions: V.K. and S.M. both equally contributed to the literature search, writing the original draft of the review. SM conceptualized the review and supervised for the overall completion. V.K. is supported by Institutional doctoral fellowship from BITs-Pilani (Hyderabad). S.M. is supported by OPERA grant from BITS-Pilani (Hyderabad). All authors have read and agreed to the published version of the manuscript.

Funding: This work was funded by BITS-Pilani (Hyderabad). The grant named OPERA (Outstanding Potential in excellence in Research and Academics) has been awarded to Shuvadeep Maity as Early career grant.

Institutional Review Board Statement: Not applicable.

Informed Consent Statement: Not applicable.

Data Availability Statement: Not applicable.

Acknowledgments: S.M. and V.K. acknowledge BITs-Pilani (Hyderabad) for providing constant support.

Conflicts of Interest: The authors declare no conflict of interest.

\begin{abstract}
Abbreviations
ER-Endoplasmic reticulum; Mito-Mitochondria; MAM-Mitochondria associated; ER membrane; MFN-Mitofusin; IP3R - Inositol triphosphate receptor; VDAC—Voltage-dependent anion channel; GRP75/78 - Glucose-regulated protein 75/78; PTPIP51-Protein tyrosine phosphatase interacting protein 51 ; VAPB - Vesicle-associated membrane protein-associated protein B; SERCASarco/endoplasmic reticulum Calcium-ATPase; IRE1-Inositol requiring enzyme 1; PERK-Protein kinase RNA-like endoplasmic reticulum kinase; ATF6/4-Activating transcription factor 6/4; OMMOuter mitochondrial membrane; IMM —-Inner mitochondrial membrane; HSP 70—Heat shock protein 70; GADD34-Growth arrest and DNA damage-inducible 34; ATAD3A-ATPase family AAA domain-containing protein 3; DRP1-Dynamin-1-like protein; MFF-Mitochondrial fission factor; Sig-1R—Sigma-1 receptor; STX17—Syntaxin 17; MITOL/MARCH-Mitochondrial ubiquitin ligase/Membrane-associated RING-CH E3 ubiquitin ligase; CXN-Calnexin; ERAD-ER-associated degradation; TIMC/TOMC - Protein translocase complexes of IMM and OMM mediating mitochondrial protein import; TMX1-Thioredoxin Related Transmembrane Protein 1; MiD51-Mitochondrial dynamic protein MID51; SCAF1—Super complex assembly factor 1; RIDD—IRE1 $\alpha$-dependent decay;
\end{abstract}


XBP1-X-box binding protein 1; eIF2 $\alpha$-Eukaryotic Initiation Factor 2; LRRK2-Leucine-rich repeat kinase 2.

\section{References}

1. Chang, C.-W.; Chen, Y.-S.; Tsay, Y.-G.; Han, C.-L.; Chen, Y.-J.; Yang, C.-C.; Hung, K.-F.; Lin, C.-H.; Huang, T.-Y.; Kao, S.-Y.; et al. ROS-independent ER stress-mediated NRF2 activation promotes warburg effect to maintain stemness-associated properties of cancer-initiating cells. Cell Death Dis. 2018, 9, 194. [CrossRef] [PubMed]

2. López-Crisosto, C.; Bravo-Sagua, R.; Rodriguez-Peña, M.; Mera, C.; Castro, P.F.; Quest, A.F.G.; Rothermel, B.A.; Cifuentes, M.; Lavandero, S. ER-to-mitochondria miscommunication and metabolic diseases. Biochim. Biophys. Acta 2015, 1852, $2096-2105$. [CrossRef] [PubMed]

3. Gordaliza-Alaguero, I.; Cantó, C.; Zorzano, A. Metabolic implications of organelle-mitochondria communication. EMBO Rep. 2019, 20, e47928. [CrossRef] [PubMed]

4. Moltedo, O.; Remondelli, P.; Amodio, G. The Mitochondria-Endoplasmic Reticulum Contacts and Their Critical Role in Aging and Age-Associated Diseases. Front Cell Dev. Biol. 2019, 7, 172. [CrossRef]

5. Bernhard, W.; Haguenau, F.; Gautier, A.; Oberling, C. [Submicroscopical structure of cytoplasmic basophils in the liver, pancreas and salivary gland; study of ultrafine slices by electron microscope]. Z. Zellforsch. Mikrosk. Anat. 1952, 37, 281-300. [CrossRef]

6. Bernhard, W.; Rouiller, C. Close Topographical Relationship between Mitochondria and Ergastoplasm of Liver Cells in a Definite Phase of Cellular Activity. J. Biophys. Biochem. Cytol. 1956, 2, 73-78. [CrossRef]

7. Bernhard, W.; Rouiller, C. Microbodies and the problem of mitochondrial regeneration in liver cells. J. Biophys. Biochem. Cytol. 1956, 2, 355-360.

8. Copeland, D.E.; Dalton, A.J. An association between mitochondria and the endoplasmic reticulum in cells of the pseudobranch gland of a teleost. J. Biophys. Biochem. Cytol. 1959, 5, 393-396. [CrossRef]

9. Jain, A.; Shivanna, K.R. Loss of viability during storage is associated with changes in membrane phospholipid. Phytochemistry 1989, 28, 999-1002. [CrossRef]

10. Vance, J.E. Newly made phosphatidylserine and phosphatidylethanolamine are preferentially translocated between rat liver mitochondria and endoplasmic reticulum. J. Biol. Chem. 1991, 266, 89-97. [CrossRef]

11. Rusiñol, A.E.; Cui, Z.; Chen, M.H.; Vance, J.E. A unique mitochondria-associated membrane fraction from rat liver has a high capacity for lipid synthesis and contains pre-Golgi secretory proteins including nascent lipoproteins. J. Biol. Chem. 1994, 269, 27494-27502. [CrossRef]

12. Giacomello, M.; Pellegrini, L. The coming of age of the mitochondria-ER contact: A matter of thickness. Cell Death Differ. 2016, 23, 1417-1427. [CrossRef] [PubMed]

13. Csordás, G.; Renken, C.; Várnai, P.; Walter, L.; Weaver, D.; Buttle, K.F.; Balla, T.; Mannella, C.A.; Hajnóczky, G. Structural and functional features and significance of the physical linkage between ER and mitochondria. J. Cell Biol. 2006, 174, 915-921. [CrossRef] [PubMed]

14. Lee, S.; Min, A.K.-T. The Interface Between ER and Mitochondria: Molecular Compositions and Functions. Mol. Cells 2018, 41, 1000-1007. [PubMed]

15. Ngoh, G.A.; Papanicolaou, K.N.; Walsh, K. Loss of mitofusin 2 promotes endoplasmic reticulum stress. J. Biol. Chem. 2012, 287, 20321-20332. [CrossRef]

16. Chu, Q.; Martinez, T.F.; Novak, S.W.; Donaldson, C.J.; Tan, D.; Vaughan, J.M.; Chang, T.; Diedrich, J.K.; Andrade, L.; Kim, A.; et al. Regulation of the ER stress response by a mitochondrial microprotein. Nat. Commun. 2019, 10, 4883. [CrossRef]

17. Rendleman, J.; Cheng, Z.; Maity, S.; Kastelic, N.; Munschauer, M.; Allgoewer, K.; Teo, G.; Zhang, Y.B.M.; Lei, A.; Parker, B.; et al. New insights into the cellular temporal response to proteostatic stress. eLife 2018, 7. [CrossRef]

18. Carrara, M.; Prischi, F.; Ali, M.M.U. UPR Signal Activation by Luminal Sensor Domains. Int. J. Mol. Sci. 2013, 14, 6454-6466. [CrossRef]

19. Shyu, P.; Ng, B.S.H.; Ho, N.; Chaw, R.; Seah, Y.L.; Marvalim, C.; Thibault, G. Membrane phospholipid alteration causes chronic ER stress through early degradation of homeostatic ER-resident proteins. Sci. Rep. 2019, 9, 1-15. [CrossRef]

20. Promlek, T.; Ishiwata-Kimata, Y.; Shido, M.; Sakuramoto, M.; Kohno, K.; Kimata, Y. Membrane aberrancy and unfolded proteins activate the endoplasmic reticulum stress sensor Ire1 in different ways. Mol. Biol. Cell 2011, 22, 3520-3532. [CrossRef]

21. Volmer, R.; van der Ploeg, K.; Ron, D. Membrane lipid saturation activates endoplasmic reticulum unfolded protein response transducers through their transmembrane domains. Proc. Natl. Acad. Sci. USA 2013, 110, 4628-4633. [CrossRef] [PubMed]

22. Hou, N.S.; Gutschmidt, A.; Choi, D.Y.; Pather, K.; Shi, X.; Watts, J.L.; Hoppe, T.; Taubert, S. Activation of the endoplasmic reticulum unfolded protein response by lipid disequilibrium without disturbed proteostasis in vivo. Proc. Natl. Acad. Sci. USA 2014, 111, E2271-E2280. [CrossRef] [PubMed]

23. Wang, P.; Li, J.; Sha, B. The ER stress sensor PERK luminal domain functions as a molecular chaperone to interact with misfolded proteins. Acta Crystallogr. D. Struct. Biol. 2016, 72, 1290-1297. [CrossRef] [PubMed]

24. Carrara, M.; Prischi, F.; Ali, M.M.U. Crystal structures reveal transient PERK luminal domain tetramerization in ER stress signaling. EMBO J. 2015, 34, 1589-1600. [CrossRef] 
25. Almanza, A.; Carlesso, A.; Chintha, C.; Creedican, S.; Doultsinos, D.; Leuzzi, B.; Luís, A.; McCarthy, N.; Montibeller, L.; More, S.; et al. Endoplasmic reticulum stress signalling-From basic mechanisms to clinical applications. FEBS J. 2019, 286, 241-278. [CrossRef]

26. Nikawa, J.; Yamashita, S. IRE1 encodes a putative protein kinase containing a membrane-spanning domain and is required for inositol phototrophy in Saccharomyces cerevisiae. Mol. Microbiol. 1992, 6, 1441-1446. [CrossRef]

27. Nikawa, J.; Akiyoshi, M.; Hirata, S.; Fukuda, T. Saccharomyces cerevisiae IRE2/HAC1 is involved in IRE1-mediated KAR2 expression. Nucleic Acids Res. 1996, 24, 4222-4226. [CrossRef]

28. Wang, X.Z.; Harding, H.P.; Zhang, Y.; Jolicoeur, E.M.; Kuroda, M.; Ron, D. Cloning of mammalian Ire1 reveals diversity in the ER stress responses. EMBO J. 1998, 17, 5708-5717. [CrossRef]

29. Tirasophon, W.; Welihinda, A.A.; Kaufman, R.J. A stress response pathway from the endoplasmic reticulum to the nucleus requires a novel bifunctional protein kinase/endoribonuclease (Ire1p) in mammalian cells. Genes Dev. 1998, 12, 1812-1824. [CrossRef]

30. Tirasophon, W.; Lee, K.; Callaghan, B.; Welihinda, A.; Kaufman, R.J. The endoribonuclease activity of mammalian IRE1 autoregulates its mRNA and is required for the unfolded protein response. Genes Dev. 2000, 14, 2725-2736. [CrossRef]

31. Bertolotti, A.; Zhang, Y.; Hendershot, L.M.; Harding, H.P.; Ron, D. Dynamic interaction of BiP and ER stress transducers in the unfolded-protein response. Nat. Cell Biol. 2000, 2, 326-332. [CrossRef] [PubMed]

32. Korennykh, A.V.; Egea, P.F.; Korostelev, A.A.; Finer-Moore, J.; Zhang, C.; Shokat, K.M.; Stroud, R.M.; Walter, P. The unfolded protein response signals through high-order assembly of Ire1. Nature 2009, 457, 687-693. [CrossRef] [PubMed]

33. Uemura, A.; Oku, M.; Mori, K.; Yoshida, H. Unconventional splicing of XBP1 mRNA occurs in the cytoplasm during the mammalian unfolded protein response. J. Cell Sci. 2009, 122, 2877-2886. [CrossRef]

34. Cox, J.S.; Walter, P. A novel mechanism for regulating activity of a transcription factor that controls the unfolded protein response. Cell 1996, 87, 391-404. [CrossRef]

35. Junjappa, R.P.; Patil, P.; Bhattarai, K.R.; Kim, H.-R.; Chae, H.-J. IRE1 $\alpha$ Implications in Endoplasmic Reticulum Stress-Mediated Development and Pathogenesis of Autoimmune Diseases. Front. Immunol. 2018, 9, 1289. [CrossRef]

36. Acosta-Alvear, D.; Zhou, Y.; Blais, A.; Tsikitis, M.; Lents, N.H.; Arias, C.; Lennon, C.J.; Kluger, Y.; Dynlacht, B.D. XBP1 controls diverse cell type- and condition-specific transcriptional regulatory networks. Mol. Cell 2007, 27, 53-66. [CrossRef]

37. Moore, K.A.; Hollien, J. The unfolded protein response in secretory cell function. Annu. Rev. Genet. 2012, 46, 165-183. [CrossRef]

38. Shaffer, A.L.; Shapiro-Shelef, M.; Iwakoshi, N.N.; Lee, A.-H.; Qian, S.-B.; Zhao, H.; Yu, X.; Yang, L.; Tan, B.K.; Rosenwald, A.; et al. $\mathrm{XBP1}$, downstream of Blimp-1, expands the secretory apparatus and other organelles, and increases protein synthesis in plasma cell differentiation. Immunity 2004, 21, 81-93. [CrossRef]

39. Hollien, J.; Lin, J.H.; Li, H.; Stevens, N.; Walter, P.; Weissman, J.S. Regulated Ire1-dependent decay of messenger RNAs in mammalian cells. J. Cell Biol. 2009, 186, 323-331. [CrossRef]

40. Moore, K.; Hollien, J. Ire1-mediated decay in mammalian cells relies on mRNA sequence, structure, and translational status. Mol. Biol. Cell 2015, 26, 2873-2884. [CrossRef]

41. Yang, H.; Niemeijer, M.; van de Water, B.; Beltman, J.B. ATF6 Is a Critical Determinant of CHOP Dynamics during the Unfolded Protein Response. iScience 2020, 23, 100860. [CrossRef] [PubMed]

42. Yoshida, H.; Matsui, T.; Yamamoto, A.; Okada, T.; Mori, K. XBP1 mRNA is induced by ATF6 and spliced by IRE1 in response to ER stress to produce a highly active transcription factor. Cell 2001, 107, 881-891. [CrossRef]

43. Cox, J.S.; Shamu, C.E.; Walter, P. Transcriptional induction of genes encoding endoplasmic reticulum resident proteins requires a transmembrane protein kinase. Cell 1993, 73, 1197-1206. [CrossRef]

44. Shen, X.; Ellis, R.E.; Lee, K.; Liu, C.Y.; Yang, K.; Solomon, A.; Yoshida, H.; Morimoto, R.; Kurnit, D.M.; Mori, K.; et al Complementary signaling pathways regulate the unfolded protein response and are required for C. elegans development. Cell 2001, 107, 893-903. [CrossRef]

45. Hollien, J.; Weissman, J.S. Decay of endoplasmic reticulum-localized mRNAs during the unfolded protein response. Science 2006, 313, 104-107. [CrossRef]

46. Urano, F.; Wang, X.; Bertolotti, A.; Zhang, Y.; Chung, P.; Harding, H.P.; Ron, D. Coupling of stress in the ER to activation of JNK protein kinases by transmembrane protein kinase IRE1. Science 2000, 287, 664-666. [CrossRef]

47. Harding, H.P.; Zhang, Y.; Ron, D. Protein translation and folding are coupled by an endoplasmic-reticulum-resident kinase. Nature 1999, 398, 90. [CrossRef]

48. Haze, K.; Yoshida, H.; Yanagi, H.; Yura, T.; Mori, K. Mammalian transcription factor ATF6 is synthesized as a transmembrane protein and activated by proteolysis in response to endoplasmic reticulum stress. Mol. Biol. Cell 1999, 10, 3787-3799. [CrossRef]

49. Haze, K.; Okada, T.; Yoshida, H.; Yanagi, H.; Yura, T.; Negishi, M.; Mori, K. Identification of the G13 (cAMP-response-elementbinding protein-related protein) gene product related to activating transcription factor 6 as a transcriptional activator of the mammalian unfolded protein response. Biochem. J. 2001, 355, 19-28. [CrossRef]

50. Kawahara, T.; Yanagi, H.; Yura, T.; Mori, K. Endoplasmic reticulum stress-induced mRNA splicing permits synthesis of transcription factor Hac1p/Ern4p that activates the unfolded protein response. Mol. Biol. Cell 1997, 8, 1845-1862. [CrossRef]

51. Urano, F.; Calfon, M.; Yoneda, T.; Yun, C.; Kiraly, M.; Clark, S.G.; Ron, D. A survival pathway for Caenorhabditis elegans with a blocked unfolded protein response. J. Cell Biol. 2002, 158, 639-646. [CrossRef] [PubMed] 
52. Calfon, M.; Zeng, H.; Urano, F.; Till, J.H.; Hubbard, S.R.; Harding, H.P.; Clark, S.G.; Ron, D. IRE1 couples endoplasmic reticulum load to secretory capacity by processing the XBP-1 mRNA. Nature 2002, 415, 92-96. [CrossRef] [PubMed]

53. Harding, H.P.; Zhang, Y.; Bertolotti, A.; Zeng, H.; Ron, D. Perk is essential for translational regulation and cell survival during the unfolded protein response. Mol. Cell 2000, 5, 897-904. [CrossRef]

54. Adams, S.L.; Safer, B.; Anderson, W.F.; Merrick, W.C. Eukaryotic initiation complex formation. Evidence for two distinct pathways. J. Biol. Chem. 1975, 250, 9083-9089. [CrossRef]

55. Walter, P.; Ron, D. The Unfolded Protein Response: From Stress Pathway to Homeostatic Regulation. Science 2011, 334, 1081-1086. [CrossRef]

56. Riezman, H.; Hay, R.; Gasser, S.; Daum, G.; Schneider, G.; Witte, C.; Schatz, G. The outer membrane of yeast mitochondria: Isolation of outside-out sealed vesicles. EMBO J. 1983, 2, 1105-1111. [CrossRef]

57. Kornmann, B.; Currie, E.; Collins, S.R.; Schuldiner, M.; Nunnari, J.; Weissman, J.S.; Walter, P. An ER-mitochondria tethering complex revealed by a synthetic biology screen. Science 2009, 325, 477-481. [CrossRef]

58. Kornmann, B.; Walter, P. ERMES-mediated ER-mitochondria contacts: Molecular hubs for the regulation of mitochondrial biology. J. Cell Sci. 2010, 123, 1389-1393. [CrossRef]

59. Stoica, R.; Paillusson, S.; Gomez-Suaga, P.; Mitchell, J.C.; Lau, D.H.; Gray, E.H.; Sancho, R.M.; Vizcay-Barrena, G.; De Vos, K.J.; Shaw, C.E.; et al. ALS/FTD-associated FUS activates GSK-3 $\beta$ to disrupt the VAPB-PTPIP51 interaction and ER-mitochondria associations. EMBO Rep. 2016, 17, 1326-1342. [CrossRef]

60. Norkett, R.; Modi, S.; Birsa, N.; Atkin, T.A.; Ivankovic, D.; Pathania, M.; Trossbach, S.V.; Korth, C.; Hirst, W.D.; Kittler, J.T. DISC1dependent Regulation of Mitochondrial Dynamics Controls the Morphogenesis of Complex Neuronal Dendrites. J. Biol. Chem. 2016, 291, 613-629. [CrossRef]

61. Brunstein, M.; Wicker, K.; Hérault, K.; Heintzmann, R.; Oheim, M. Full-field dual-color 100-nm super-resolution imaging reveals organization and dynamics of mitochondrial and ER networks. Opt. Express 2013, 21, 26162-26173. [CrossRef] [PubMed]

62. Park, S.J.; Lee, S.B.; Suh, Y.; Kim, S.-J.; Lee, N.; Hong, J.-H.; Park, C.; Woo, Y.; Ishizuka, K.; Kim, J.-H.; et al. DISC1 Modulates Neuronal Stress Responses by Gate-Keeping ER-Mitochondria Ca Transfer through the MAM. Cell Rep. 2017, 21, 2748-2759. [CrossRef] [PubMed]

63. Csordás, G.; Várnai, P.; Golenár, T.; Roy, S.; Purkins, G.; Schneider, T.G.; Balla, T.; Hajnóczky, G. Imaging interorganelle contacts and local calcium dynamics at the ER-mitochondrial interface. Mol. Cell 2010, 39, 121-132. [CrossRef] [PubMed]

64. Lim, Y.; Cho, I.-T.; Schoel, L.J.; Cho, G.; Golden, J.A. Hereditary spastic paraplegia-linked REEP1 modulates endoplasmic reticulum/mitochondria contacts. Ann. Neurol. 2015, 78, 679-696. [CrossRef]

65. De Vos, K.J.; Mórotz, G.M.; Stoica, R.; Tudor, E.L.; Lau, K.-F.; Ackerley, S.; Warley, A.; Shaw, C.E.; Miller, C.C.J. VAPB interacts with the mitochondrial protein PTPIP51 to regulate calcium homeostasis. Hum. Mol. Genet. 2012, 21, 1299-1311. [CrossRef]

66. Hung, V.; Lam, S.S.; Udeshi, N.D.; Svinkina, T.; Guzman, G.; Mootha, V.K.; Carr, S.A.; Ting, A.Y. Proteomic mapping of cytosol-facing outer mitochondrial and ER membranes in living human cells by proximity biotinylation. eLife 2017, 6. [CrossRef]

67. Cho, I.-T.; Adelmant, G.; Lim, Y.; Marto, J.A.; Cho, G.; Golden, J.A. Ascorbate peroxidase proximity labeling coupled with biochemical fractionation identifies promoters of endoplasmic reticulum-mitochondrial contacts. J. Biol. Chem. 2017, 292, 16382-16392. [CrossRef]

68. Baudier, J. ATAD3 proteins: Brokers of a mitochondria-endoplasmic reticulum connection in mammalian cells. Biol. Rev. Camb. Philos. Soc. 2018, 93, 827-844. [CrossRef]

69. Kwak, C.; Shin, S.; Park, J.-S.; Jung, M.; Nhung, T.T.M.; Kang, M.-G.; Lee, C.; Kwon, T.-H.; Park, S.K.; Mun, J.Y.; et al. Contact-ID, a tool for profiling organelle contact sites, reveals regulatory proteins of mitochondrial-associated membrane formation. Proc. Natl. Acad. Sci. USA 2020, 117, 12109-12120. [CrossRef]

70. Misaka, T.; Murakawa, T.; Nishida, K.; Omori, Y.; Taneike, M.; Omiya, S.; Molenaar, C.; Uno, Y.; Yamaguchi, O.; Takeda, J.; et al. FKBP8 protects the heart from hemodynamic stress by preventing the accumulation of misfolded proteins and endoplasmic reticulum-associated apoptosis in mice. J. Mol. Cell. Cardiol. 2018, 114, 93-104. [CrossRef]

71. Saita, S.; Shirane, M.; Ishitani, T.; Shimizu, N.; Nakayama, K.I. Role of the ANKMY2-FKBP38 axis in regulation of the Sonic hedgehog (Shh) signaling pathway. J. Biol. Chem. 2014, 289, 25639-25654. [CrossRef] [PubMed]

72. Saita, S.; Shirane, M.; Nakayama, K.I. Selective escape of proteins from the mitochondria during mitophagy. Nat. Commun. 2013, 4, 1410. [CrossRef] [PubMed]

73. Rowland, A.A.; Voeltz, G.K. Endoplasmic reticulum-mitochondria contacts: Function of the junction. Nat. Rev. Mol. Cell Biol. 2012, 13, 607-625. [CrossRef] [PubMed]

74. Vance, J.E. MAM (mitochondria-associated membranes) in mammalian cells: Lipids and beyond. Biochim. Biophys. Acta 2014, 1841, 595-609. [CrossRef]

75. Rone, M.B.; Midzak, A.S.; Issop, L.; Rammouz, G.; Jagannathan, S.; Fan, J.; Ye, X.; Blonder, J.; Veenstra, T.; Papadopoulos, V. Identification of a dynamic mitochondrial protein complex driving cholesterol import, trafficking, and metabolism to steroid hormones. Mol. Endocrinol. 2012, 26, 1868-1882. [CrossRef]

76. Tsujishita, Y.; Hurley, J.H. Structure and lipid transport mechanism of a StAR-related domain. Nat. Struct. Biol. 2000, 7, 408-414.

77. Kentala, H.; Weber-Boyvat, M.; Olkkonen, V.M. OSBP-Related Protein Family: Mediators of Lipid Transport and Signaling at Membrane Contact Sites. Int. Rev. Cell Mol. Biol. 2016, 321, 299-340. 
78. Reitz, J.; Gehrig-Burger, K.; Strauss, J.F., 3rd; Gimpl, G. Cholesterol interaction with the related steroidogenic acute regulatory lipid-transfer (START) domains of StAR (STARD1) and MLN64 (STARD3). FEBS J. 2008, 275, 1790-1802. [CrossRef]

79. Hoffmann, M.; Bellance, N.; Rossignol, R.; Koopman, W.J.H.; Willems, P.H.G.M.; Mayatepek, E.; Bossinger, O.; Distelmaier, F.C. elegans ATAD-3 is essential for mitochondrial activity and development. PLoS ONE 2009, 4, e7644. [CrossRef]

80. Desai, R.; Frazier, A.E.; Durigon, R.; Patel, H.; Jones, A.W.; Dalla Rosa, I.; Lake, N.J.; Compton, A.G.; Mountford, H.S.; Tucker, E.J.; et al. ATAD3 gene cluster deletions cause cerebellar dysfunction associated with altered mitochondrial DNA and cholesterol metabolism. Brain 2017, 140, 1595-1610. [CrossRef]

81. Xia, M.; Zhang, Y.; Jin, K.; Lu, Z.; Zeng, Z.; Xiong, W. Communication between mitochondria and other organelles: A brand-new perspective on mitochondria in cancer. Cell Biosci. 2019, 9, 27. [CrossRef] [PubMed]

82. Veeresh, P.; Kaur, H.; Sarmah, D.; Mounica, L.; Verma, G.; Kotian, V.; Kesharwani, R.; Kalia, K.; Borah, A.; Wang, X.; et al. Endoplasmic reticulum-mitochondria crosstalk: From junction to function across neurological disorders. Ann. N. Y. Acad. Sci. 2019, 1457, 41-60. [CrossRef] [PubMed]

83. Hirabayashi, Y.; Kwon, S.-K.; Paek, H.; Pernice, W.M.; Paul, M.A.; Lee, J.; Erfani, P.; Raczkowski, A.; Petrey, D.S.; Pon, L.A.; et al. ER-mitochondria tethering by PDZD8 regulates Ca dynamics in mammalian neurons. Science 2017, 358, 623-630. [CrossRef] [PubMed]

84. Iwasawa, R.; Mahul-Mellier, A.-L.; Datler, C.; Pazarentzos, E.; Grimm, S. Fis1 and Bap31 bridge the mitochondria-ER interface to establish a platform for apoptosis induction. EMBO J. 2011, 30, 556-568. [CrossRef] [PubMed]

85. Lisbona, F.; Rojas-Rivera, D.; Thielen, P.; Zamorano, S.; Todd, D.; Martinon, F.; Glavic, A.; Kress, C.; Lin, J.H.; Walter, P.; et al. BAX inhibitor-1 is a negative regulator of the ER stress sensor IRE1alpha. Mol. Cell 2009, 33, 679-691. [CrossRef]

86. Woehlbier, U.; Hetz, C. Modulating stress responses by the UPRosome: A matter of life and death. Trends Biochem. Sci. 2011, 36, 329-337. [CrossRef] [PubMed]

87. Verfaillie, T.; Rubio, N.; Garg, A.D.; Bultynck, G.; Rizzuto, R.; Decuypere, J.-P.; Piette, J.; Linehan, C.; Gupta, S.; Samali, A.; et al. PERK is required at the ER-mitochondrial contact sites to convey apoptosis after ROS-based ER stress. Cell Death Differ. 2012, 19, 1880-1891. [CrossRef]

88. Mori, T.; Hayashi, T.; Hayashi, E.; Su, T.-P. Sigma-1 Receptor Chaperone at the ER-Mitochondrion Interface Mediates the Mitochondrion-ER-Nucleus Signaling for Cellular Survival. PLoS ONE 2013, 8, e76941. [CrossRef]

89. Tavernier, S.J.; Osorio, F.; Vandersarren, L.; Vetters, J.; Vanlangenakker, N.; Van Isterdael, G.; Vergote, K.; De Rycke, R.; Parthoens, E.; van de Laar, L.; et al. Regulated IRE1-dependent mRNA decay sets the threshold for dendritic cell survival. Nat. Cell Biol. 2017, 19, 698-710. [CrossRef]

90. Romero-Ramirez, L.; Cao, H.; Nelson, D.; Hammond, E.; Lee, A.-H.; Yoshida, H.; Mori, K.; Glimcher, L.H.; Denko, N.C.; Giaccia, A.J.; et al. XBP1 is essential for survival under hypoxic conditions and is required for tumor growth. Cancer Res. 2004, 64, 5943-5947. [CrossRef]

91. Son, S.M.; Byun, J.; Roh, S.-E.; Kim, S.J.; Mook-Jung, I. Reduced IRE1 $\alpha$ mediates apoptotic cell death by disrupting calcium homeostasis via the InsP3 receptor. Cell Death Dis. 2014, 5, e1188. [CrossRef] [PubMed]

92. Lerner, A.G.; Upton, J.-P.; Praveen, P.V.K.; Ghosh, R.; Nakagawa, Y.; Igbaria, A.; Shen, S.; Nguyen, V.; Backes, B.J.; Heiman, M.; et al. IRE1 $\alpha$ Induces Thioredoxin-Interacting Protein to Activate the NLRP3 Inflammasome and Promote Programmed Cell Death under Irremediable ER Stress. Cell Metab. 2012, 16, 250-264. [CrossRef] [PubMed]

93. Upton, J.-P.; Wang, L.; Han, D.; Wang, E.S.; Huskey, N.E.; Lim, L.; Truitt, M.; McManus, M.T.; Ruggero, D.; Goga, A.; et al. IRE1 $\alpha$ cleaves select microRNAs during ER stress to derepress translation of proapoptotic Caspase-2. Science 2012, 338, 818-822. [CrossRef] [PubMed]

94. Bravo-Sagua, R.; Rodriguez, A.E.; Kuzmicic, J.; Gutierrez, T.; Lopez-Crisosto, C.; Quiroga, C.; Diaz-Elizondo, J.; Chiong, M.; Gillette, T.G.; Rothermel, B.A.; et al. Cell Death and Survival Through the Endoplasmic Reticulum- Mitochondrial Axis. Curr. Mol. Med. 2013, 13, 317-329. [CrossRef] [PubMed]

95. The endoplasmic reticulum-mitochondria connection: One touch, multiple functions. Biochim. Biophys. Acta (BBA) Bioenerg. 2014, 1837, 461-469. [CrossRef]

96. Mizushima, N.; Yoshimori, T.; Ohsumi, Y. The Role of Atg Proteins in Autophagosome Formation. Annu. Rev. Cell Develop. Biol. 2011, 27, 107-132. [CrossRef]

97. Perrotta, I. The origin of the autophagosomal membrane in human atherosclerotic plaque: A preliminary ultrastructural study. Ultrastruct. Pathol. 2017, 41, 327-334. [CrossRef]

98. Rizzuto, R. Close Contacts with the Endoplasmic Reticulum as Determinants of Mitochondrial Ca2 Responses. Science 1998, 280, 1763-1766. [CrossRef]

99. Hayashi, T.; Rizzuto, R.; Hajnoczky, G.; Su, T.-P. MAM: More than just a housekeeper. Trends Cell Biol. 2009, 19, 81-88. [CrossRef]

100. Matsunaga, K.; Saitoh, T.; Tabata, K.; Omori, H.; Satoh, T.; Kurotori, N.; Maejima, I.; Shirahama-Noda, K.; Ichimura, T.; Isobe, T.; et al. Two Beclin 1-binding proteins, Atg14L and Rubicon, reciprocally regulate autophagy at different stages. Nat. Cell Biol. 2009, 11, 385-396. [CrossRef]

101. Matsunaga, K.; Morita, E.; Saitoh, T.; Akira, S.; Ktistakis, N.T.; Izumi, T.; Noda, T.; Yoshimori, T. Autophagy requires endoplasmic reticulum targeting of the PI3-kinase complex via Atg14L. J. Cell Biol. 2010, 190, 511-521. [CrossRef] [PubMed] 
102. Axe, E.L.; Walker, S.A.; Manifava, M.; Chandra, P.; Roderick, H.L.; Habermann, A.; Griffiths, G.; Ktistakis, N.T. Autophagosome formation from membrane compartments enriched in phosphatidylinositol 3-phosphate and dynamically connected to the endoplasmic reticulum. J. Cell Biol. 2008, 182, 685-701. [CrossRef] [PubMed]

103. Szabadkai, G.; Bianchi, K.; Várnai, P.; De Stefani, D.; Wieckowski, M.R.; Cavagna, D.; Nagy, A.I.; Balla, T.; Rizzuto, R. Chaperonemediated coupling of endoplasmic reticulum and mitochondrial $\mathrm{Ca}^{2+}$ channels. J. Cell Biol. 2006, 175, 901-911. [CrossRef] [PubMed]

104. Fujita, N.; Hayashi-Nishino, M.; Fukumoto, H.; Omori, H.; Yamamoto, A.; Noda, T.; Yoshimori, T. An Atg4B mutant hampers the lipidation of LC3 paralogues and causes defects in autophagosome closure. Mol. Biol. Cell 2008, 19, 4651-4659. [CrossRef] [PubMed]

105. Mutsaers, A.J.; Walkley, C.R. Cells of origin in osteosarcoma: Mesenchymal stem cells or osteoblast committed cells? Bone 2014, 62, 56-63. [CrossRef] [PubMed]

106. Bobrovnikova-Marjon, E.; Grigoriadou, C.; Pytel, D.; Zhang, F.; Ye, J.; Koumenis, C.; Cavener, D.; Diehl, J.A. PERK promotes cancer cell proliferation and tumor growth by limiting oxidative DNA damage. Oncogene 2010, 29, 3881-3895. [CrossRef]

107. Blais, J.D.; Addison, C.L.; Edge, R.; Falls, T.; Zhao, H.; Wary, K.; Koumenis, C.; Harding, H.P.; Ron, D.; Holcik, M.; et al. Perkdependent translational regulation promotes tumor cell adaptation and angiogenesis in response to hypoxic stress. Mol. Cell. Biol. 2006, 26, 9517-9532. [CrossRef]

108. Ji, G.-R.; Yu, N.-C.; Xue, X.; Li, Z.-G. PERK-mediated Autophagy in Osteosarcoma Cells Resists ER Stress-induced Cell Apoptosis. Int. J. Biol. Sci. 2015, 11, 803-812. [CrossRef]

109. Ding, W.-X.; Yin, X.-M. Mitophagy: Mechanisms, pathophysiological roles, and analysis. Biol. Chem. 2012, 393, 547-564. [CrossRef]

110. Gelmetti, V.; De Rosa, P.; Torosantucci, L.; Marini, E.S.; Romagnoli, A.; Di Rienzo, M.; Arena, G.; Vignone, D.; Fimia, G.M.; Valente, E.M. PINK1 and BECN1 relocalize at mitochondria-associated membranes during mitophagy and promote ER-mitochondria tethering and autophagosome formation. Autophagy 2017, 13, 654-669. [CrossRef]

111. Wu, W.; Li, W.; Chen, H.; Jiang, L.; Zhu, R.; Feng, D. FUNDC1 is a novel mitochondrial-associated-membrane (MAM) protein required for hypoxia-induced mitochondrial fission and mitophagy. Autophagy 2016, 12, 1675-1676. [CrossRef] [PubMed]

112. Jin, G.; Xu, C.; Zhang, X.; Long, J.; Rezaeian, A.H.; Liu, C.; Furth, M.E.; Kridel, S.; Pasche, B.; Bian, X.-W.; et al. Atad3a suppresses Pink1-dependent mitophagy to maintain homeostasis of hematopoietic progenitor cells. Nat. Immunol. 2018, 19, 29-40. [CrossRef] [PubMed]

113. Yang, C.; Suda, T. Hyperactivated mitophagy in hematopoietic stem cells. Nat. Immunol. 2018, 19, 2-3. [CrossRef] [PubMed]

114. Yan, C.; Liu, J.; Gao, J.; Sun, Y.; Zhang, L.; Song, H.; Xue, L.; Zhan, L.; Gao, G.; Ke, Z.; et al. IRE1 promotes neurodegeneration through autophagy-dependent neuron death in the Drosophila model of Parkinson's disease. Cell Death Dis. 2019, 10, 800. [CrossRef] [PubMed]

115. Valdés, P.; Mercado, G.; Vidal, R.L.; Molina, C.; Parsons, G.; Court, F.A.; Martinez, A.; Galleguillos, D.; Armentano, D.; Schneider, B.L.; et al. Control of dopaminergic neuron survival by the unfolded protein response transcription factor XBP1. Proc. Natl. Acad. Sci. USA 2014, 111, 6804-6809. [CrossRef]

116. Mishra, P.; Chan, D.C. Mitochondrial dynamics and inheritance during cell division, development and disease. Nat. Rev. Mol. Cell Biol. 2014, 15, 634-646. [CrossRef]

117. Parone, P.A.; Da Cruz, S.; Tondera, D.; Mattenberger, Y.; James, D.I.; Maechler, P.; Barja, F.; Martinou, J.-C. Preventing mitochondrial fission impairs mitochondrial function and leads to loss of mitochondrial DNA. PLoS ONE 2008, 3, e3257. [CrossRef]

118. Otera, H.; Mihara, K. Molecular mechanisms and physiologic functions of mitochondrial dynamics. J. Biochem. 2011, 149, $241-251$. [CrossRef]

119. Varadi, A.; Johnson-Cadwell, L.I.; Cirulli, V.; Yoon, Y.; Allan, V.J.; Rutter, G.A. Cytoplasmic dynein regulates the subcellular distribution of mitochondria by controlling the recruitment of the fission factor dynamin-related protein-1. J. Cell Sci. 2004, 117, 4389-4400. [CrossRef]

120. Campello, S.; Scorrano, L. Mitochondrial shape changes: Orchestrating cell pathophysiology. EMBO Rep. 2010, 11, 678-684. [CrossRef]

121. Legesse-Miller, A.; Massol, R.H.; Kirchhausen, T. Constriction and Dnm1p recruitment are distinct processes in mitochondrial fission. Mol. Biol. Cell 2003, 14, 1953-1963. [CrossRef] [PubMed]

122. Ingerman, E.; Perkins, E.M.; Marino, M.; Mears, J.A.; McCaffery, J.M.; Hinshaw, J.E.; Nunnari, J. Dnm1 forms spirals that are structurally tailored to fit mitochondria. J. Cell Biol. 2005, 170, 1021-1027. [CrossRef] [PubMed]

123. Mears, J.A.; Lackner, L.L.; Fang, S.; Ingerman, E.; Nunnari, J.; Hinshaw, J.E. Conformational changes in Dnm1 support a contractile mechanism for mitochondrial fission. Nat. Struct. Mol. Biol. 2011, 18, 20-26. [CrossRef] [PubMed]

124. Gandre-Babbe, S.; van der Bliek, A.M. The novel tail-anchored membrane protein Mff controls mitochondrial and peroxisomal fission in mammalian cells. Mol. Biol. Cell 2008, 19, 2402-2412. [CrossRef]

125. Otera, H.; Wang, C.; Cleland, M.M.; Setoguchi, K.; Yokota, S.; Youle, R.J.; Mihara, K. Mff is an essential factor for mitochondrial recruitment of Drp1 during mitochondrial fission in mammalian cells. J. Cell Biol. 2010, 191, 1141-1158. [CrossRef]

126. Otera, H.; Mihara, K. Discovery of the membrane receptor for mitochondrial fission GTPase Drp1. Small GTPases 2011, 2, 167-172. [CrossRef] 
127. Palmer, C.S.; Osellame, L.D.; Laine, D.; Koutsopoulos, O.S.; Frazier, A.E.; Ryan, M.T. MiD49 and MiD51, new components of the mitochondrial fission machinery. EMBO Rep. 2011, 12, 565-573. [CrossRef]

128. Losón, O.C.; Song, Z.; Chen, H.; Chan, D.C. Fis1, Mff, MiD49, and MiD51 mediate Drp1 recruitment in mitochondrial fission. Mol. Biol. Cell 2013, 24, 659-667. [CrossRef]

129. Richter, V.; Palmer, C.S.; Osellame, L.D.; Singh, A.P.; Elgass, K.; Stroud, D.A.; Sesaki, H.; Kvansakul, M.; Ryan, M.T. Structural and functional analysis of MiD51, a dynamin receptor required for mitochondrial fission. J. Cell Biol. 2014, 204, 477-486. [CrossRef]

130. Elgass, K.D.; Smith, E.A.; LeGros, M.A.; Larabell, C.A.; Ryan, M.T. Analysis of ER-mitochondria contacts using correlative fluorescence microscopy and soft X-ray tomography of mammalian cells. J. Cell Sci. 2015, 128, 2795-2804. [CrossRef]

131. Friedman, J.R.; Lackner, L.L.; West, M.; DiBenedetto, J.R.; Nunnari, J.; Voeltz, G.K. ER tubules mark sites of mitochondrial division. Science 2011, 334, 358-362. [CrossRef] [PubMed]

132. Giorgi, C.; Ito, K.; Lin, H.-K.; Santangelo, C.; Wieckowski, M.R.; Lebiedzinska, M.; Bononi, A.; Bonora, M.; Duszynski, J.; Bernardi, R.; et al. PML regulates apoptosis at endoplasmic reticulum by modulating calcium release. Science 2010, 330, $1247-1251$. [CrossRef] [PubMed]

133. Betz, C.; Stracka, D.; Prescianotto-Baschong, C.; Frieden, M.; Demaurex, N.; Hall, M.N. Feature Article: mTOR complex 2-Akt signaling at mitochondria-associated endoplasmic reticulum membranes (MAM) regulates mitochondrial physiology. Proc. Natl. Acad. Sci. USA 2013, 110, 12526-12534. [CrossRef] [PubMed]

134. Marchi, S.; Rimessi, A.; Giorgi, C.; Baldini, C.; Ferroni, L.; Rizzuto, R.; Pinton, P. Akt kinase reducing endoplasmic reticulum Ca ${ }^{2+}$ release protects cells from $\mathrm{Ca}^{2+}$-dependent apoptotic stimuli. Biochem. Biophys. Res. Commun. 2008, 375, 501-505. [CrossRef] [PubMed]

135. Bononi, A.; Bonora, M.; Marchi, S.; Missiroli, S.; Poletti, F.; Giorgi, C.; Pandolfi, P.P.; Pinton, P. Identification of PTEN at the ER and MAMs and its regulation of Ca2 signaling and apoptosis in a protein phosphatase-dependent manner. Cell Death Differ. 2013, 20, 1631-1643. [CrossRef] [PubMed]

136. Tubbs, E.; Theurey, P.; Vial, G.; Bendridi, N.; Bravard, A.; Chauvin, M.-A.; Ji-Cao, J.; Zoulim, F.; Bartosch, B.; Ovize, M.; et al. Mitochondria-associated endoplasmic reticulum membrane (MAM) integrity is required for insulin signaling and is implicated in hepatic insulin resistance. Diabetes 2014, 63, 3279-3294. [CrossRef]

137. Hou, X.; Liu, Y.; Liu, H.; Chen, X.; Liu, M.; Che, H.; Guo, F.; Wang, C.; Zhang, D.; Wu, J.; et al. PERK silence inhibits glioma cell growth under low glucose stress by blockage of p-AKT and subsequent HK2's mitochondria translocation. Sci. Rep. 2015, 5, 9065. [CrossRef]

138. Sanchez-Alvarez, M.; Del Pozo, M.A.; Bakal, C. AKT-mTOR signaling modulates the dynamics of IRE1 RNAse activity by regulating ER-mitochondria contacts. Sci. Rep. 2017, 7, 16497. [CrossRef]

139. Ames, A. CNS energy metabolism as related to function. Brain Res. Rev. 2000, 34, 42-68. [CrossRef]

140. Issad, T.; Kuo, M. O-GlcNAc modification of transcription factors, glucose sensing and glucotoxicity. Trends Endocrinol. Metab. 2008, 19, 380-389. [CrossRef]

141. van der Harg, J.M.; van Heest, J.C.; Bangel, F.N.; Patiwael, S.; van Weering, J.R.T.; Scheper, W. The UPR reduces glucose metabolism via IRE1 signaling. Biochim. Biophys. Acta Mol. Cell Res. 2017, 1864, 655-665. [CrossRef] [PubMed]

142. Swayne, T.C.; Zhou, C.; Boldogh, I.R.; Charalel, J.K.; McFaline-Figueroa, J.R.; Thoms, S.; Yang, C.; Leung, G.; McInnes, J.; Erdmann, R.; et al. Role for cER and Mmr1p in anchorage of mitochondria at sites of polarized surface growth in budding yeast. Curr. Biol. 2011, 21, 1994-1999. [CrossRef] [PubMed]

143. Murley, A.; Lackner, L.L.; Osman, C.; West, M.; Voeltz, G.K.; Walter, P.; Nunnari, J. ER-associated mitochondrial division links the distribution of mitochondria and mitochondrial DNA in yeast. eLife 2013, 2, e00422. [CrossRef] [PubMed]

144. Lewis, S.C.; Uchiyama, L.F.; Nunnari, J. ER-mitochondria contacts couple mtDNA synthesis with mitochondrial division in human cells. Science 2016, 353, aaf5549. [CrossRef] [PubMed]

145. Zhao, Y.; Sun, X.; Hu, D.; Prosdocimo, D.A.; Hoppel, C.; Jain, M.K.; Ramachandran, R.; Qi, X. ATAD3A oligomerization causes neurodegeneration by coupling mitochondrial fragmentation and bioenergetics defects. Nat. Commun. 2019, 10, 1371. [CrossRef] [PubMed]

146. Teng, Y.; Ren, X.; Li, H.; Shull, A.; Kim, J.; Cowell, J.K. Mitochondrial ATAD3A combines with GRP78 to regulate the WASF3 metastasis-promoting protein. Oncogene 2016, 35, 333-343. [CrossRef]

147. Tran, D.M.; Ishiwata-Kimata, Y.; Mai, T.C.; Kubo, M.; Kimata, Y. The unfolded protein response alongside the diauxic shift of yeast cells and its involvement in mitochondria enlargement. Sci. Rep. 2019, 9, 12780. [CrossRef]

148. Carreras-Sureda, A.; Jaña, F.; Urra, H.; Durand, S.; Mortenson, D.E.; Sagredo, A.; Bustos, G.; Hazari, Y.; Ramos-Fernández, E.; Sassano, M.L.; et al. Publisher Correction: Non-canonical function of IRE1 $\alpha$ determines mitochondria-associated endoplasmic reticulum composition to control calcium transfer and bioenergetics. Nat. Cell Biol. 2019, 21, 913. [CrossRef]

149. Takeda, K.; Nagashima, S.; Shiiba, I.; Uda, A.; Tokuyama, T.; Ito, N.; Fukuda, T.; Matsushita, N.; Ishido, S.; Iwawaki, T.; et al. MITOL prevents ER stress-induced apoptosis by IRE $1 \alpha$ ubiquitylation at ER -mitochondria contact sites. EMBO J. 2019, 38, e100999. [CrossRef]

150. Naon, D.; Zaninello, M.; Giacomello, M.; Varanita, T.; Grespi, F.; Lakshminaranayan, S.; Serafini, A.; Semenzato, M.; Herkenne, S.; Hernández-Alvarez, M.I.; et al. Critical reappraisal confirms that Mitofusin 2 is an endoplasmic reticulum-mitochondria tether. Proc. Natl. Acad. Sci. USA 2016, 113, 11249-11254. [CrossRef] 
151. Muñoz, J.P.; Ivanova, S.; Sánchez-Wandelmer, J.; Martínez-Cristóbal, P.; Noguera, E.; Sancho, A.; Díaz-Ramos, A.; HernándezAlvarez, M.I.; Sebastián, D.; Mauvezin, C.; et al. Mfn2 modulates the UPR and mitochondrial function via repression of PERK. EMBO J. 2013, 32, 2348-2361. [CrossRef] [PubMed]

152. Ron, D.; Walter, P. Signal integration in the endoplasmic reticulum unfolded protein response. Nat. Rev. Mol. Cell Biol. 2007, 8 , 519-529. [CrossRef] [PubMed]

153. Cullinan, S.B.; Zhang, D.; Hannink, M.; Arvisais, E.; Kaufman, R.J.; Diehl, J.A. Nrf2 is a direct PERK substrate and effector of PERK-dependent cell survival. Mol. Cell. Biol. 2003, 23, 7198-7209. [CrossRef] [PubMed]

154. Rainbolt, T.K.; Saunders, J.M.; Wiseman, R.L. Stress-responsive regulation of mitochondria through the ER unfolded protein response. Trends Endocrinol. Metab. 2014, 25, 528-537. [CrossRef]

155. Gupta, S.; Read, D.E.; Deepti, A.; Cawley, K.; Gupta, A.; Oommen, D.; Verfaillie, T.; Matus, S.; Smith, M.A.; Mott, J.L.; et al. Perk-dependent repression of miR-106b-25 cluster is required for ER stress-induced apoptosis. Cell Death Dis. 2012, 3, e333. [CrossRef]

156. Wu, H.; Li, Z.; Wang, Y.; Yang, P.; Li, Z.; Li, H.; Wu, C. MiR-106b-mediated Mfn2 suppression is critical for PKM2 induced mitochondrial fusion. Am. J. Cancer Res. 2016, 6, 2221-2234.

157. Lebeau, J.; Saunders, J.M.; Moraes, V.W.R.; Madhavan, A.; Madrazo, N.; Anthony, M.C.; Wiseman, R.L. The PERK Arm of the Unfolded Protein Response Regulates Mitochondrial Morphology during Acute Endoplasmic Reticulum Stress. Cell Rep. 2018, 22, 2827-2836. [CrossRef]

158. Toyofuku, T.; Okamoto, Y.; Ishikawa, T.; Sasawatari, S.; Kumanogoh, A. LRRK2 regulates endoplasmic reticulum-mitochondrial tethering through the PERK-mediated ubiquitination pathway. EMBO J. 2020, 39, e100875. [CrossRef]

159. van Vliet, A.R.; Giordano, F.; Gerlo, S.; Segura, I.; Van Eygen, S.; Molenberghs, G.; Rocha, S.; Houcine, A.; Derua, R.; Verfaillie, T.; et al. The ER Stress Sensor PERK Coordinates ER-Plasma Membrane Contact Site Formation through Interaction with Filamin-A and F-Actin Remodeling. Mol. Cell 2017, 65, 885-899.e6. [CrossRef]

160. Gomes, L.C.; Di Benedetto, G.; Scorrano, L. During autophagy mitochondria elongate, are spared from degradation and sustain cell viability. Nat. Cell Biol. 2011, 13, 589-598. [CrossRef]

161. Gohil, V.M.; Sheth, S.A.; Nilsson, R.; Wojtovich, A.P.; Lee, J.H.; Perocchi, F.; Chen, W.; Clish, C.B.; Ayata, C.; Brookes, P.S.; et al. Nutrient-sensitized screening for drugs that shift energy metabolism from mitochondrial respiration to glycolysis. Nat. Biotechnol. 2010, 28, 249-255. [CrossRef] [PubMed]

162. Balsa, E.; Soustek, M.S.; Thomas, A.; Cogliati, S.; García-Poyatos, C.; Martín-García, E.; Jedrychowski, M.; Gygi, S.P.; Enriquez, J.A.; Puigserver, P. ER and Nutrient Stress Promote Assembly of Respiratory Chain Supercomplexes through the PERK-eIF2 $\alpha$ Axis. Mol. Cell 2019, 74, 877-890.e6. [CrossRef] [PubMed]

163. Chen, S.; Henderson, A.; Petriello, M.C.; Romano, K.A.; Gearing, M.; Miao, J.; Schell, M.; Sandoval-Espinola, W.J.; Tao, J.; Sha, B.; et al. Trimethylamine N-Oxide Binds and Activates PERK to Promote Metabolic Dysfunction. Cell Metab. 2019, 30, 1141-1151.e5. [CrossRef] [PubMed]

164. Kato, H.; Okabe, K.; Miyake, M.; Hattori, K.; Fukaya, T.; Tanimoto, K.; Beini, S.; Mizuguchi, M.; Torii, S.; Arakawa, S.; et al. ER-resident sensor PERK is essential for mitochondrial thermogenesis in brown adipose tissue. Life Sci. Alliance 2020, 3. [CrossRef]

165. Shoulders, M.D.; Ryno, L.M.; Genereux, J.C.; Moresco, J.J.; Tu, P.G.; Wu, C.; Yates, J.R., 3rd; Su, A.I.; Kelly, J.W.; Wiseman, R.L. Stress-independent activation of XBP1s and/or ATF6 reveals three functionally diverse ER proteostasis environments. Cell Rep. 2013, 3, 1279-1292. [CrossRef]

166. Paxman, R.; Plate, L.; Blackwood, E.A.; Glembotski, C.; Powers, E.T.; Wiseman, R.L.; Kelly, J.W. Pharmacologic ATF6 activating compounds are metabolically activated to selectively modify endoplasmic reticulum proteins. eLife 2018, 7. [CrossRef]

167. Chen, J.J.; Genereux, J.C.; Qu, S.; Hulleman, J.D.; Shoulders, M.D.; Wiseman, R.L. ATF6 activation reduces the secretion and extracellular aggregation of destabilized variants of an amyloidogenic protein. Chem. Biol. 2014, 21, 1564-1574. [CrossRef]

168. Cooley, C.B.; Ryno, L.M.; Plate, L.; Morgan, G.J.; Hulleman, J.D.; Kelly, J.W.; Wiseman, R.L. Unfolded protein response activation reduces secretion and extracellular aggregation of amyloidogenic immunoglobulin light chain. Proc. Natl. Acad. Sci. USA 2014, 111, 13046-13051. [CrossRef]

169. Burkewitz, K.; Feng, G.; Dutta, S.; Kelley, C.A.; Steinbaugh, M.; Cram, E.J.; Mair, W.B. Atf-6 Regulates Lifespan through ER-Mitochondrial Calcium Homeostasis. Cell Rep. 2020, 32, 108125. [CrossRef]

170. Wang, S.; Hu, B.; Ding, Z.; Dang, Y.; Wu, J.; Li, D.; Liu, X.; Xiao, B.; Zhang, W.; Ren, R.; et al. ATF6 safeguards organelle homeostasis and cellular aging in human mesenchymal stem cells. Cell Discov. 2018, 4, 2. [CrossRef]

171. Druelle, C.; Drullion, C.; Deslé, J.; Martin, N.; Saas, L.; Cormenier, J.; Malaquin, N.; Huot, L.; Slomianny, C.; Bouali, F.; et al. ATF6 $\alpha$ regulates morphological changes associated with senescence in human fibroblasts. Oncotarget 2016, 7, 67699-67715. [CrossRef] [PubMed]

172. Misra, J.; Kim, D.-K.; Choi, W.; Koo, S.-H.; Lee, C.-H.; Back, S.-H.; Kaufman, R.J.; Choi, H.-S. Transcriptional cross talk between orphan nuclear receptor ERR $\gamma$ and transmembrane transcription factor ATF6 $\alpha$ coordinates endoplasmic reticulum stress response. Nucleic Acids Res. 2013, 41, 6960-6974. [CrossRef] [PubMed]

173. Martindale, J.J.; Fernandez, R.; Thuerauf, D.; Whittaker, R.; Gude, N.; Sussman, M.A.; Glembotski, C.C. Endoplasmic reticulum stress gene induction and protection from ischemia/reperfusion injury in the hearts of transgenic mice with a tamoxifen-regulated form of ATF6. Circ. Res. 2006, 98, 1186-1193. [CrossRef] [PubMed] 
174. Belmont, P.J.; Tadimalla, A.; Chen, W.J.; Martindale, J.J.; Thuerauf, D.J.; Marcinko, M.; Gude, N.; Sussman, M.A.; Glembotski, C.C. Coordination of growth and endoplasmic reticulum stress signaling by regulator of calcineurin 1 (RCAN1), a novel ATF6-inducible gene. J. Biol. Chem. 2008, 283, 14012-14021. [CrossRef] [PubMed]

175. Jin, J.-K.; Blackwood, E.A.; Azizi, K.; Thuerauf, D.J.; Fahem, A.G.; Hofmann, C.; Kaufman, R.J.; Doroudgar, S.; Glembotski, C.C. ATF6 Decreases Myocardial Ischemia/Reperfusion Damage and Links ER Stress and Oxidative Stress Signaling Pathways in the Heart. Circ. Res. 2017, 120, 862-875. [CrossRef]

176. Ozcan, L.; Ghorpade, D.S.; Zheng, Z.; de Souza, J.C.; Chen, K.; Bessler, M.; Bagloo, M.; Schrope, B.; Pestell, R.; Tabas, I. Hepatocyte DACH1 Is Increased in Obesity via Nuclear Exclusion of HDAC4 and Promotes Hepatic Insulin Resistance. Cell Rep. 2016, 15, 2214-2225. [CrossRef] [PubMed]

177. Chen, X.; Zhang, F.; Gong, Q.; Cui, A.; Zhuo, S.; Hu, Z.; Han, Y.; Gao, J.; Sun, Y.; Liu, Z.; et al. Hepatic ATF6 Increases Fatty Acid Oxidation to Attenuate Hepatic Steatosis in Mice Through Peroxisome Proliferator-Activated Receptor $\alpha$. Diabetes 2016, 65, 1904-1915. [CrossRef]

178. Przedborski, S.; Vila, M.; Jackson-Lewis, V. Series Introduction: Neurodegeneration: What is it and where are we? J. Clin. Investig. 2003, 111, 3-10. [CrossRef]

179. (Neuro)degenerated Mitochondria-ER contacts. Biochem. Biophys. Res. Commun. 2017, 483, 1096-1109. [CrossRef]

180. Poston, C.N.; Krishnan, S.C.; Bazemore-Walker, C.R. In-depth proteomic analysis of mammalian mitochondria-associated membranes (MAM). J. Proteomics 2013, 79, 219-230. [CrossRef]

181. Caselli, R.J.; Knopman, D.S.; Bu, G. An agnostic reevaluation of the amyloid cascade hypothesis of Alzheimer's disease pathogenesis: The role of APP homeostasis. Alzheimers. Dement. 2020, 16, 1582-1590. [CrossRef] [PubMed]

182. Area-Gomez, E.; Del Carmen Lara Castillo, M.; Tambini, M.D.; Guardia-Laguarta, C.; de Groof, A.J.C.; Madra, M.; Ikenouchi, J.; Umeda, M.; Bird, T.D.; Sturley, S.L.; et al. Upregulated function of mitochondria-associated ER membranes in Alzheimer disease. EMBO J. 2012, 31, 4106-4123. [CrossRef] [PubMed]

183. Zampese, E.; Fasolato, C.; Kipanyula, M.J.; Bortolozzi, M.; Pozzan, T.; Pizzo, P. Presenilin 2 modulates endoplasmic reticulum (ER)-mitochondria interactions and $\mathrm{Ca}^{2+}$ cross-talk. Proc. Natl. Acad. Sci. USA 2011, 108, 2777-2782. [CrossRef] [PubMed]

184. Hoozemans, J.J.M.; van Haastert, E.S.; Nijholt, D.A.T.; Rozemuller, A.J.M.; Eikelenboom, P.; Scheper, W. The unfolded protein response is activated in pretangle neurons in Alzheimer's disease hippocampus. Am. J. Pathol. 2009, 174, 1241-1251. [CrossRef]

185. Köhler, C.; Dinekov, M.; Götz, J. Granulovacuolar degeneration and unfolded protein response in mouse models of tauopathy and A $\beta$ amyloidosis. Neurobiol. Dis. 2014, 71, 169-179. [CrossRef]

186. Ni, H.; Rui, Q.; Li, D.; Gao, R.; Chen, G. The Role of IRE1 Signaling in the Central Nervous System Diseases. Curr. Neuropharmacol. 2018, 16, 1340-1347. [CrossRef]

187. Lee, J.H.; Won, S.M.; Suh, J.; Son, S.J.; Moon, G.J.; Park, U.J.; Gwag, B.J. Induction of the unfolded protein response and cell death pathway in Alzheimer's disease, but not in aged Tg2576 mice. Exp. Mol. Med. 2010, 42, 386-394. [CrossRef]

188. Liu, S.-Y.; Wang, W.; Cai, Z.-Y.; Yao, L.-F.; Chen, Z.-W.; Wang, C.-Y.; Zhao, B.; Li, K.-S. Polymorphism -116C/G of human X-box-binding protein 1 promoter is associated with risk of Alzheimer's disease. CNS Neurosci. Ther. 2013, 19, 229-234. [CrossRef]

189. Bezprozvanny, I.; Mattson, M.P. Neuronal calcium mishandling and the pathogenesis of Alzheimer's disease. Trends Neurosci. 2008, 31, 454-463. [CrossRef]

190. Casas-Tinto, S.; Zhang, Y.; Sanchez-Garcia, J.; Gomez-Velazquez, M.; Rincon-Limas, D.E.; Fernandez-Funez, P. The ER stress factor XBP1s prevents amyloid-beta neurotoxicity. Hum. Mol. Genet. 2011, 20, 2144-2160. [CrossRef]

191. Wang, Y.; Alam, G.N.; Ning, Y.; Visioli, F.; Dong, Z.; Nör, J.E.; Polverini, P.J. The unfolded protein response induces the angiogenic switch in human tumor cells through the PERK/ATF4 pathway. Cancer Res. 2012, 72, 5396-5406. [CrossRef] [PubMed]

192. Okamoto, K.; Hirai, S.; Iizuka, T.; Yanagisawa, T.; Watanabe, M. Reexamination of granulovacuolar degeneration. Acta Neuropathol. 1991, 82, 340-345. [CrossRef] [PubMed]

193. Funk, K.E.; Mrak, R.E.; Kuret, J. Granulovacuolar degeneration (GVD) bodies of Alzheimer's disease (AD) resemble late-stage autophagic organelles. Neuropathol. Appl. Neurobiol. 2011, 37, 295-306. [CrossRef] [PubMed]

194. Ho, Y.-S.; Yang, X.; Lau, J.C.-F.; Hung, C.H.-L.; Wuwongse, S.; Zhang, Q.; Wang, J.; Baum, L.; So, K.-F.; Chang, R.C.-C. Endoplasmic reticulum stress induces tau pathology and forms a vicious cycle: Implication in Alzheimer's disease pathogenesis. J. Alzheimer's Dis. 2012, 28, 839-854. [CrossRef]

195. Jiang, H.-Y.; Wek, R.C. Phosphorylation of the alpha-subunit of the eukaryotic initiation factor-2 (eIF2alpha) reduces protein synthesis and enhances apoptosis in response to proteasome inhibition. J. Biol. Chem. 2005, 280, 14189-14202. [CrossRef]

196. Newman, J.; Rissman, R.A.; Sarsoza, F.; Kim, R.C.; Dick, M.; Bennett, D.A.; Cotman, C.W.; Rohn, T.T.; Head, E. Caspase-cleaved tau accumulation in neurodegenerative diseases associated with tau and alpha-synuclein pathology. Acta Neuropathol. 2005, 110, 135-144. [CrossRef]

197. Bruch, J.; Xu, H.; Rösler, T.W.; De Andrade, A.; Kuhn, P.; Lichtenthaler, S.F.; Arzberger, T.; Winklhofer, K.F.; Müller, U.; Höglinger, G.U. PERK activation mitigates tau pathology in vitro and in vivo. EMBO Mol. Med. 2017, 9, 371-384. [CrossRef]

198. Fortin, D.L.; Troyer, M.D.; Nakamura, K.; Kubo, S.-I.; Anthony, M.D.; Edwards, R.H. Lipid rafts mediate the synaptic localization of alpha-synuclein. J. Neurosci. 2004, 24, 6715-6723. [CrossRef]

199. Ziviani, E.; Tao, R.N.; Whitworth, A.J. Drosophila parkin requires PINK1 for mitochondrial translocation and ubiquitinates mitofusin. Proc. Natl. Acad. Sci. USA 2010, 107, 5018-5023. [CrossRef] 
200. Narendra, D.; Tanaka, A.; Suen, D.-F.; Youle, R.J. Parkin is recruited selectively to impaired mitochondria and promotes their autophagy. J. Cell Biol. 2008, 183, 795-803. [CrossRef]

201. Calì, T.; Ottolini, D.; Negro, A.; Brini, M. Enhanced parkin levels favor ER-mitochondria crosstalk and guarantee Ca2 transfer to sustain cell bioenergetics. Biochim. Biophys. Acta (BBA) Mol. Basis Dis. 2013, 1832, 495-508. [CrossRef] [PubMed]

202. Hoozemans, J.J.M.; van Haastert, E.S.; Eikelenboom, P.; de Vos, R.A.I.; Rozemuller, J.M.; Scheper, W. Activation of the unfolded protein response in Parkinson's disease. Biochem. Biophys. Res. Commun. 2007, 354, 707-711. [CrossRef]

203. Elvira, R.; Cha, S.J.; Noh, G.-M.; Kim, K.; Han, J. PERK-Mediated eIF2 $\alpha$ Phosphorylation Contributes to The Protection of Dopaminergic Neurons from Chronic Heat Stress in Drosophila. Int. J. Mol. Sci. 2020, 21, 845. [CrossRef] [PubMed]

204. Zhang, H.-Y.; Wang, Z.-G.; Lu, X.-H.; Kong, X.-X.; Wu, F.-Z.; Lin, L.; Tan, X.; Ye, L.-B.; Xiao, J. Endoplasmic reticulum stress: Relevance and therapeutics in central nervous system diseases. Mol. Neurobiol. 2015, 51, 1343-1352. [CrossRef] [PubMed]

205. Fouillet, A.; Levet, C.; Virgone, A.; Robin, M.; Dourlen, P.; Rieusset, J.; Belaidi, E.; Ovize, M.; Touret, M.; Nataf, S.; et al. ER stress inhibits neuronal death by promoting autophagy. Autophagy 2012, 8, 915-926. [CrossRef] [PubMed]

206. Si, L.; Xu, T.; Wang, F.; Liu, Q.; Cui, M. X-box-binding protein 1-modified neural stem cells for treatment of Parkinson's disease. Neural Regen. Res. 2012, 7, 736-740.

207. Fink, J.K. The hereditary spastic paraplegias. Neurodegener. Dis. 2005, 794-802.

208. Park, S.H.; Zhu, P.-P.; Parker, R.L.; Blackstone, C. Hereditary spastic paraplegia proteins REEP1, spastin, and atlastin-1 coordinate microtubule interactions with the tubular ER network. J. Clin. Investig. 2010, 120, 1097-1110. [CrossRef]

209. Filadi, R.; Greotti, E.; Turacchio, G.; Luini, A.; Pozzan, T.; Pizzo, P. Presenilin 2 Modulates Endoplasmic Reticulum-Mitochondria Coupling by Tuning the Antagonistic Effect of Mitofusin 2. Cell Rep. 2016, 15, 2226-2238. [CrossRef]

210. Robberecht, W.; Philips, T. The changing scene of amyotrophic lateral sclerosis. Nat. Rev. Neurosci. 2013, 14, 248-264. [CrossRef]

211. DeJesus-Hernandez, M.; Mackenzie, I.R.; Boeve, B.F.; Boxer, A.L.; Baker, M.; Rutherford, N.J.; Nicholson, A.M.; Finch, N.A.; Flynn, H.; Adamson, J.; et al. Expanded GGGGCC hexanucleotide repeat in noncoding region of C9ORF72 causes chromosome 9p-linked FTD and ALS. Neuron 2011, 72, 245-256. [CrossRef] [PubMed]

212. Johnson, J.O.; Mandrioli, J.; Benatar, M.; Abramzon, Y.; Van Deerlin, V.M.; Trojanowski, J.Q.; Gibbs, J.R.; Brunetti, M.; Gronka, S.; Wuu, J.; et al. Exome sequencing reveals VCP mutations as a cause of familial ALS. Neuron 2010, 68, 857-864. [CrossRef] [PubMed]

213. Winton, M.J.; Van Deerlin, V.M.; Kwong, L.K.; Yuan, W.; Wood, E.M.; Yu, C.-E.; Schellenberg, G.D.; Rademakers, R.; Caselli, R.; Karydas, A.; et al. A90V TDP-43 variant results in the aberrant localization of TDP-43 in vitro. FEBS Lett. 2008, 582, $2252-2256$. [CrossRef] [PubMed]

214. Dewey, C.M.; Cenik, B.; Sephton, C.F.; Johnson, B.A.; Herz, J.; Yu, G. TDP-43 aggregation in neurodegeneration: Are stress granules the key? Brain Res. 2012, 1462, 16-25. [CrossRef]

215. Stoica, R.; De Vos, K.J.; Paillusson, S.; Mueller, S.; Sancho, R.M.; Lau, K.-F.; Vizcay-Barrena, G.; Lin, W.-L.; Xu, Y.-F.; Lewis, J.; et al. ER-mitochondria associations are regulated by the VAPB-PTPIP51 interaction and are disrupted by ALS/FTD-associated TDP-43. Nat. Commun. 2014, 5, 3996. [CrossRef]

216. Kikuchi, H.; Almer, G.; Yamashita, S.; Guégan, C.; Nagai, M.; Xu, Z.; Sosunov, A.A.; McKhann, G.M., 2nd; Przedborski, S. Spinal cord endoplasmic reticulum stress associated with a microsomal accumulation of mutant superoxide dismutase-1 in an ALS model. Proc. Natl. Acad. Sci. USA 2006, 103, 6025-6030. [CrossRef]

217. Hardiman, O.; van den Berg, L.H.; Kiernan, M.C. Clinical diagnosis and management of amyotrophic lateral sclerosis. Nat. Rev. Neurol. 2011, 7, 639-649. [CrossRef]

218. Dion, P.A.; Daoud, H.; Rouleau, G.A. Genetics of motor neuron disorders: New insights into pathogenic mechanisms. Nat. Rev. Genet. 2009, 10, 769-782. [CrossRef]

219. Wang, L.; Popko, B.; Roos, R.P. The unfolded protein response in familial amyotrophic lateral sclerosis. Human Mol. Genet. 2011, 20, 1008-1015. [CrossRef]

220. De Giorgio, F.; Maduro, C.; Fisher, E.M.C.; Acevedo-Arozena, A. Transgenic and physiological mouse models give insights into different aspects of amyotrophic lateral sclerosis. Dis. Model. Mech. 2019, 12. [CrossRef]

221. Watanabe, S.; Ilieva, H.; Tamada, H.; Nomura, H.; Komine, O.; Endo, F.; Jin, S.; Mancias, P.; Kiyama, H.; Yamanaka, K. Mitochondria-associated membrane collapse is a common pathomechanism in SIGMAR1- and SOD1-linked ALS. EMBO Mol. Med. 2016, 8, 1421-1437. [CrossRef] [PubMed]

222. Gusella, J.F.; Wexler, N.S.; Michael Conneally, P.; Naylor, S.L.; Anderson, M.A.; Tanzi, R.E.; Watkins, P.C.; Ottina, K.; Wallace, M.R.; Sakaguchi, A.Y.; et al. A polymorphic DNA marker genetically linked to Huntington's disease. Nature 1983, 306, 234-238. [CrossRef] [PubMed]

223. Andrew, S.E.; Paul Goldberg, Y.; Kremer, B.; Telenius, H.; Theilmann, J.; Adam, S.; Starr, E.; Squitieri, F.; Lin, B.; Kalchman, M.A.; et al. The relationship between trinucleotide (CAG) repeat length and clinical features of Huntington's disease. Nat. Genet. 1993, 4, 398-403. [CrossRef] [PubMed]

224. Warner, V.D.; Lynch, D.M.; Meszoely, C.A.; Dykstra, W.G., Jr. Synthesis and in vivo antimalarial evaluation of isopropyl [(4-chlorophenyl)amino]iminomethylcarbamimidate. J. Pharm. Sci. 1977, 66, 418-419. [CrossRef] [PubMed]

225. Kambouris, M.; Bohlega, S.; Al-Tahan, A.; Meyer, B.F. Localization of the gene for a novel autosomal recessive neurodegenerative Huntington-like disorder to 4p15.3. Am. J. Hum. Genet. 2000, 66, 445-452. [CrossRef] 
226. Reijonen, S.; Putkonen, N.; Nørremølle, A.; Lindholm, D.; Korhonen, L. Inhibition of endoplasmic reticulum stress counteracts neuronal cell death and protein aggregation caused by N-terminal mutant huntingtin proteins. Exp. Cell Res. 2008, 314, 950-960. [CrossRef]

227. Wang, H.; Blais, J.; Ron, D.; Cardozo, T. Structural determinants of PERK inhibitor potency and selectivity. Chem. Biol. Drug Des. 2010, 76, 480-495. [CrossRef]

228. Lee, H.; Noh, J.-Y.; Oh, Y.; Kim, Y.; Chang, J.-W.; Chung, C.-W.; Lee, S.-T.; Kim, M.; Ryu, H.; Jung, Y.-K. IRE1 plays an essential role in ER stress-mediated aggregation of mutant huntingtin via the inhibition of autophagy flux. Hum. Mol. Genet. 2012, 21, 101-114. [CrossRef]

229. Vidal, R.L.; Figueroa, A.; Court, F.A.; Thielen, P.; Molina, C.; Wirth, C.; Caballero, B.; Kiffin, R.; Segura-Aguilar, J.; Cuervo, A.M.; et al. Targeting the UPR transcription factor XBP1 protects against Huntington's disease through the regulation of FoxO1 and autophagy. Hum. Mol. Genet. 2012, 21, 2245-2262. [CrossRef]

230. Zuleta, A.; Vidal, R.L.; Armentano, D.; Parsons, G.; Hetz, C. AAV-mediated delivery of the transcription factor XBP1s into the striatum reduces mutant Huntingtin aggregation in a mouse model of Huntington's disease. Biochem. Biophys. Res. Commun. 2012, 420, 558-563. [CrossRef]

231. Leitman, J.; Barak, B.; Benyair, R.; Shenkman, M.; Ashery, U.; Ulrich Hartl, F.; Lederkremer, G.Z. ER Stress-Induced eIF2-alpha Phosphorylation Underlies Sensitivity of Striatal Neurons to Pathogenic Huntingtin. PLoS ONE 2014, 9, e90803. [CrossRef] [PubMed]

232. Ganz, J.; Shacham, T.; Kramer, M.; Shenkman, M.; Eiger, H.; Weinberg, N.; Iancovici, O.; Roy, S.; Simhaev, L.; Da'adoosh, B.; et al. A novel specific PERK activator reduces toxicity and extends survival in Huntington's disease models. Sci. Rep. 2020, 10, 6875. [CrossRef] [PubMed]

233. Yap, Z.Y.; Park, Y.; Wortmann, S.B.; Gunning, A.C.; Lee, S.; Duraine, L.; Wilichowski, E.; Wilson, K.; Mayr, J.A.; Wagner, M.; et al. Functional interpretation of ATAD3A variants in neuro-mitochondrial phenotypes. bioRxiv 2020. [CrossRef]

234. Taalab, Y.M.; Ibrahim, N.; Maher, A.; Hassan, M.; Mohamed, W.; Moustafa, A.A.; Salama, M.; Johar, D.; Bernstein, L. Mechanisms of disordered neurodegenerative function: Concepts and facts about the different roles of the protein kinase RNA-like endoplasmic reticulum kinase (PERK). Rev. Neurosci. 2018, 29, 387-415. [CrossRef] [PubMed]

235. Nijholt, D.A.T.; van Haastert, E.S.; Rozemuller, A.J.M.; Scheper, W.; Hoozemans, J.J.M. The unfolded protein response is associated with early tau pathology in the hippocampus of tauopathies. J. Pathol. 2012, 226, 693-702. [CrossRef] [PubMed]

236. Höglinger, G.U.; Melhem, N.M.; Dickson, D.W.; Sleiman, P.M.A.; Wang, L.-S.; Klei, L.; Rademakers, R.; de Silva, R.; Litvan, I.; Riley, D.E.; et al. Identification of common variants influencing risk of the tauopathy progressive supranuclear palsy. Nat. Genet. 2011, 43, 699-705. [CrossRef]

237. McCarron, J.G.; Wilson, C.; Sandison, M.E.; Olson, M.L.; Girkin, J.M.; Saunter, C.; Chalmers, S. From Structure to Function: Mitochondrial Morphology, Motion and Shaping in Vascular Smooth Muscle. JVR 2013, 50, 357-371. [CrossRef]

238. Yu, R.; Liu, T.; Jin, S.-B.; Ning, C.; Lendahl, U.; Nistér, M.; Zhao, J. MIEF1/2 function as adaptors to recruit Drp1 to mitochondria and regulate the association of Drp1 with Mff. Sci. Rep. 2017, 7, 880. [CrossRef]

239. PACS-2: A key regulator of mitochondria-associated membranes (MAMs). Pharmacol. Res. 2020, 160, 105080. [CrossRef]

240. Kim, S.-Y.; Kim, H.J.; Kim, H.-J.; Kim, D.H.; Han, J.H.; Byeon, H.K.; Lee, K.; Kim, C.-H. HSPA5 negatively regulates lysosomal activity through ubiquitination of MUL1 in head and neck cancer. Autophagy 2018, 14, 385-403. [CrossRef]

241. Eisner, V.; Csordás, G.; Hajnóczky, G. Interactions between sarco-endoplasmic reticulum and mitochondria in cardiac and skeletal muscle-Pivotal roles in $\mathrm{Ca}^{2+}$ and reactive oxygen species signaling. J. Cell Sci. 2013, 126, 2965-2978. [CrossRef] [PubMed]

242. Area-Gomez, E.; de Groof, A.; Bonilla, E.; Montesinos, J.; Tanji, K.; Boldogh, I.; Pon, L.; Schon, E.A. A key role for MAM in mediating mitochondrial dysfunction in Alzheimer disease. Cell Death Dis. 2018, 9, 335. [CrossRef] [PubMed]

243. Brewster, J.L.; Department of Natural Sciences, Pepperdine University; Malibu, C.A. USA Signaling hubs at ER/mitochondrial membrane associations. AIMS Biophys. 2017, 4, 222-239. [CrossRef]

244. Prasad, M.; Kaur, J.; Pawlak, K.J.; Bose, M.; Whittal, R.M.; Bose, H.S. Mitochondria-associated endoplasmic reticulum membrane (MAM) regulates steroidogenic activity via steroidogenic acute regulatory protein (StAR)-voltage-dependent anion channel 2 (VDAC2) interaction. J. Biol. Chem. 2015, 290, 2604-2616. [CrossRef] [PubMed]

245. Zhao, L.; Lu, T.; Gao, L.; Fu, X.; Zhu, S.; Hou, Y. Enriched endoplasmic reticulum-mitochondria interactions result in mitochondrial dysfunction and apoptosis in oocytes from obese mice. J. Anim. Sci. Biotechnol. 2017, 8, 62. [CrossRef] [PubMed]

246. Browman, D.T.; Resek, M.E.; Zajchowski, L.D.; Robbins, S.M. Erlin-1 and erlin-2 are novel members of the prohibitin family of proteins that define lipid-raft-like domains of the ER. J. Cell Sci. 2006, 119, 3149-3160. [CrossRef]

247. Wu, S.; Zou, M.-H. Mitochondria-associated endoplasmic reticulum membranes in the heart. Arch. Biochem. Biophys. 2019, 662, 201-212. [CrossRef]

248. Weng, T.-Y.; Tsai, S.-Y.A.; Su, T.-P. Roles of sigma-1 receptors on mitochondrial functions relevant to neurodegenerative diseases. J. Biomed. Sci. 2017, 24, 74. [CrossRef]

249. Physiological roles of phosphatidylethanolamine N-methyltransferase. Biochim. Biophys. Acta (BBA) Mol. Cell Biol. Lipids 2013, 1831, 626-632. [CrossRef]

250. Endoplasmic Reticulum-Mitochondrial Contactology: Structure and Signaling Functions. Trends Cell Biol. 2018, $28,523-540$. [CrossRef] 
251. Sala-Vila, A.; Navarro-Lérida, I.; Sánchez-Alvarez, M.; Bosch, M.; Calvo, C.; López, J.A.; Calvo, E.; Ferguson, C.; Giacomello, M.; Serafini, A.; et al. Interplay between hepatic mitochondria-associated membranes, lipid metabolism and caveolin-1 in mice. Sci. Rep. 2016, 6, 27351. [CrossRef] [PubMed]

252. van Vliet, A.R.; Verfaillie, T.; Agostinis, P. New functions of mitochondria associated membranes in cellular signaling. Biochim. Biophys. Acta 2014, 1843, 2253-2262. [CrossRef] [PubMed]

253. Barazzuol, L.; Giamogante, F.; Brini, M.; Calì, T. PINK1/Parkin Mediated Mitophagy, Ca Signalling, and ER-Mitochondria Contacts in Parkinson's Disease. Int. J. Mol. Sci. 2020, 21, 1772. [CrossRef]

254. Rieusset, J. The role of endoplasmic reticulum-mitochondria contact sites in the control of glucose homeostasis: An update. Cell Death Dis. 2018, 9, 388. [CrossRef] [PubMed]

255. Theurey, P.; Rieusset, J. Mitochondria-Associated Membranes Response to Nutrient Availability and Role in Metabolic Diseases. Trends Endocrinol. Metab. 2017, 28, 32-45. [CrossRef] 